\title{
Tuning the Liquid Crystallinity of Cholesteryl-o-Carborane Dyads: Synthesis, Structure, Photoluminescence, and Mesomorphic Properties
}

\author{
Albert Ferrer-Ugalde ${ }^{1,+}+\mathbb{D}$, Arántzazu González-Campo ${ }^{1,+}{ }^{\mathbb{D}}$, José Giner Planas ${ }^{1} \mathbb{D}$, Clara Viñas ${ }^{1} \mathbb{D}$, \\ Francesc Teixidor ${ }^{1}$, Isabel M. Sáez ${ }^{2, *}$ and Rosario Núñez ${ }^{1, *, \ddagger(D)}$ \\ 1 Institut de Ciència de Materials de Barcelona, ICMAB-CSIC, Campus UAB, 08193 Bellaterra, Spain; \\ a.ferrer80@hotmail.com (A.F.-U.); agonzalez@icmab.es (A.G.-C.); jginerplanas@icmab.es (J.G.P.); \\ clara@icmab.es (C.V.); teixidor@icmab.es (F.T.) \\ 2 Agap Materials Solutions UK, Hull HU16 4RL, UK \\ * Correspondence: crapims1907@gmail.com (I.M.S.); rosario@icmab.es (R.N.) \\ + A.F.-U. and A.G.-C. contributed equally to this work. \\ $\ddagger$ Dedicated to the Professor, friend and colleague Alan Welch who has managed with his research and \\ enthusiasm at bringing boron cluster chemistry closer to the scientific community.
}

Citation: Ferrer-Ugalde, A.; GonzálezCampo, A.; Planas, J.G.; Viñas, C.;

Teixidor, F.; Sáez, I.M.; Núñez, R. Tuning the Liquid Crystallinity of Cholesteryl-o-Carborane Dyads: Synthesis, Structure, Photoluminescence, and Mesomorphic Properties. Crystals 2021, 11, 133. https://doi.org/10.3390/ cryst11020133

Academic Editor: Marina Yu. Stogniy Received: 23 December 2020

Accepted: 24 January 2021

Published: 28 January 202

Publisher's Note: MDPI stays neutral with regard to jurisdictional claims in published maps and institutional affiliations.

Copyright: (c) 2021 by the authors. Licensee MDPI, Basel, Switzerland. This article is an open access article distributed under the terms and conditions of the Creative Commons Attribution (CC BY) license (https:// creativecommons.org/licenses/by/ $4.0 /)$.

\begin{abstract}
A set of mesomorphic materials in which the $o$-carborane cluster is covalently bonded to a cholesteryl benzoate moiety (mesogen group) through a suitably designed linker is described. The olefin cross-metathesis between appropriately functionalized styrenyl-o-carborane derivatives and a terminal alkenyl cholesteryl benzoate mesogen (all type I terminal olefins) leads to the desired trans-regioisomer, which is the best-suited configuration to obtain mesomorphic properties in the final materials. The introduction of different substituents ( $=\mathrm{H}(\mathbf{M} 2)$, Me (M3), or Ph (M4)) to one of the carbon atoms of the $o$-carborane cluster $\left(\mathrm{C}_{\text {cluster }}\right)$ enables the tailoring of liquid crystalline properties. Compounds M2 and M3 show the chiral nematic $\left(\mathrm{N}^{*}\right)$ phase, whereas M4 do not show liquid crystal behavior. Weaker intermolecular interactions in the solid M3 with respect to those in M2 may allow the liquid crystallinity in $\mathbf{M} 3$ to be expressed as enantiotropic behavior, whereas breaking the stronger intermolecular interaction in the solid state of $\mathbf{M} 2$ leads directly to the isotropic state, resulting in monotropic behavior. Remarkably, M3 also displays the blue phase, which was observed neither in the chiral nematic precursor nor in the styrenyl-cholesterol model (M5) without an $o$-carborane cluster, which suggests that the presence of the cluster plays a role in stabilizing this highly twisted chiral phase. In the carborane-containing mesogens (M2 and M3), the $o$-carborane cluster can be incorporated without destroying the helical organization of the mesophase.
\end{abstract}

Keywords: boron clusters; carboranes; liquid crystals; fluorescence; cholesterol

\section{Introduction}

The liquid crystalline state (mesophase) is a state of matter that displays properties between those of conventional liquid and solid phases; this behavior can be subdivided into two types: thermotropic and lyotropic. Among these, thermotropic liquid crystals (LCs) are partially ordered anisotropic fluids that exhibit one or more mesophases in a given temperature range [1-3]. In most cases, the mesogenic behavior of an LC material is due to the combination of a rigid core with flexible groups to produce rod-like molecules that may show different types of mesophases, such as nematic (N) or smectic (Sm) [1]. Both the electronic structure and geometry determine the thermal and optical properties of the mesogen. Cholesteric liquid crystals (CLCs) are well-known chiral nematic materials that display the chiral nematic phase $\left(\mathrm{N}^{*}\right)$, where the chiral molecules are organized in parallel planes to the director and twisted in a perpendicular way throughout the director, describing a helical structure. The most important feature of CLCs is the selective reflection of circularly polarized light according to Bragg's law [4]. Due to their 1D photonic structure 
and ease of fabrication, cholesteric liquid crystals have also attracted much attention as optical sensors [5-7].

Icosahedral 1,2-dicarba-closo-dodecacarborane or o-carborane $\left(1,2-\mathrm{C}_{2} \mathrm{~B}_{10} \mathrm{H}_{12}\right)$ [8-11] have highly polarizable spherical aromaticity through $\sigma$-delocalized electron densities [12-16]. Consequently, they display characteristic electronic properties [17,18], and thermal [19-21], chemical, and photochemical stability [22,23]. All these features make them attractive and interesting systems in materials science [24-26], especially for luminescent materials [27-48], polymers [21], and Non-Linear Optical (NLO) materials, [49,50] among others [22]. The rigidity of these boron clusters promotes their use as a structural element of the rigid core in the preparation of liquid crystalline materials [51]. Boron clusters of major interest for synthesizing liquid crystals have been the 12 vertex, $p$-carborane $\left(1,12-\mathrm{C}_{2} \mathrm{~B}_{10} \mathrm{H}_{12}\right)[52,53],\left[1-\mathrm{CB}_{11} \mathrm{H}_{12}\right]^{-}$[54-56], the dianion dodecaborate $\left[\mathrm{B}_{12} \mathrm{H}_{12}\right]^{2-}$ [57], as well as the 10 vertex closo-boron clusters $1,10-\mathrm{C}_{2} \mathrm{~B}_{8} \mathrm{H}_{10},\left[1-\mathrm{CB}_{9} \mathrm{H}_{10}\right]^{-}[54,58]$. All of them are properly functionalized with suitable organic functional groups to provide a supramolecular structure with optical properties that might be modulated by external stimuli (Chart 1) [8]. Around 200 "rod-like" mesogens containing $p$-carboranes and several examples of bent-core mesogens bearing $m$-carborane $\left(1,7-\mathrm{C}_{2} \mathrm{~B}_{10} \mathrm{H}_{12}\right)$ have been reported, in which the angle formed for both substituents at the carbons of the cluster $\left(\mathrm{C}_{\mathrm{cluster}}, \mathrm{C}_{\mathrm{c}}\right)$ is $120^{\circ}$ [51]. Generally, $p$-carboranes are the preferred choice to synthesize LCs, not only because of their spherocylindrical morphology, but also for the accessibility of substitution at the antipodal $\mathrm{C}_{\mathrm{c}}$ atoms with appropriate groups, leading to an extension of the molecular shape that forms the mesogenic state (Chart 1 ). Most LCs containing $p$-carboranes show nematic phases [59], except those LCs with terminal alkyl chains with fluoride atoms that usually lead to smectic phases [60]. Nevertheless, the use of 0 -carborane, $1,2-\mathrm{C}_{2} \mathrm{~B}_{10} \mathrm{H}_{12}$, and its derivatives has barely been explored as LCs, but studies involving their use in boron-containing liposomes as potential agents for BNCT have been reported [61-64]. To our knowledge, only two examples on $o$-carborane-based LCs have been recently reported by Kaszynsky $[65,66]$. In these, $o$-carborane is used as a linear structural element with a moderate dipole moment, which is substituted at the C1 and B12 atoms to give 1,12-difunctionalized derivatives that show the smectic A (SmA) and N mesophases.

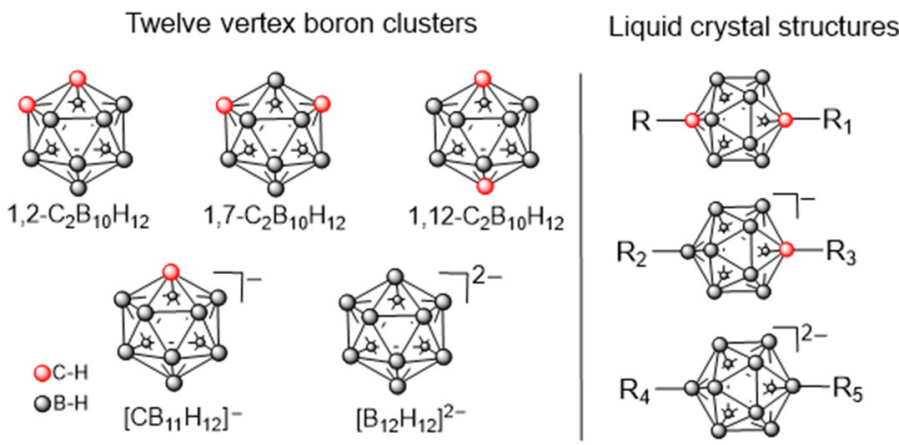

Chart 1. Representation of more usual twelve vertex boron clusters used to perform liquid crystalline materials.

There have been several reports of liquid crystals containing octasilsesquioxanes $[67,68]$, or fullerenes [69-71], as scaffold to append mesogenic moieties in order to probe the effect of a rigid structurally well-defined core on mesophase behavior. In this sense, $o$ carborane may also provide a unique inorganic polyhedral scaffold that can lead the way to the generation of a new family of this class of materials, and it may offer a new insight into the effects of these substituents on the mesophase behavior of the ensuing liquid crystalline materials.

Herein we describe for the first time the synthesis, structural characterization, and photophysical properties in solution of a set of new mesomorphic materials in which the $o$-carborane cluster is covalently bonded to a cholesteryl benzoate moiety (mesogen group) 
through a suitable methylene linker. We have assessed the influence of the $o$-carborane unit and its substituents bound to the $C_{c}$ atom on their liquid crystal properties. We have also tried to establish a relationship between the 3D crystal packing in solid state and the changes of mesophase with temperature.

\section{Results and Discussion}

\subsection{Synthesis and Characterization of Mesogens}

The chemical synthesis of linear cholesteryl-o-carborane dyads was designed to be carried out by olefin cross-metathesis between three different styrenyl-o-carborane derivatives: 1- $\left[\mathrm{CH}_{2} \mathrm{C}_{6} \mathrm{H}_{4}-4^{\prime}-\left(\mathrm{CH}=\mathrm{CH}_{2}\right)\right]-2-\mathrm{R}-1,2-$ closo- $\mathrm{C}_{2} \mathrm{~B}_{10} \mathrm{H}_{10}[\mathrm{R}=\mathrm{H}(\mathbf{1}), \mathrm{R}=$ Methyl or Me (2), $\mathrm{R}=$ Phenyl or Ph (3)] (see Scheme 1) [42], and a cholesterol derivative that contains a suitable alkenylene moiety. To this purpose, cholesteryl benzoate was adequately modified to introduce the terminal alkenylene group producing $\mathbf{M 1}$ by adaptation of the literature method (Scheme S1) [72]. A related strategy using olefin cross-metathesis in the design of liquid crystal synthesis has been reported while the current work was in progress $[73,74]$. Cross-metathesis reactions of $o$-carborane derivatives 1-3 and the mesogenic cholesterol derivative $\mathbf{M 1}$ were carried out using first-generation Grubbs catalyst in $\mathrm{CH}_{2} \mathrm{Cl}_{2}$ at reflux for $48 \mathrm{~h}$ under argon atmosphere (Scheme 1). The reactions were by ${ }^{1} \mathrm{H}$ NMR spectroscopy to the total disappearance of the starting vinyl and alkenyl protons. The white solid in the remaining suspensions, which corresponds to the homo-metathesis of the M1 side product, was filtered off, and the clear brown solutions were quenched with methanol to yield a gray precipitate that was also filtered and dried. Spectroscopic analyses proved that the latter contained a mixture of the expected final compound (M2-M4) and a small quantity of the M1 homo-metathesis compound, which is partially soluble in $\mathrm{CH}_{2} \mathrm{Cl}_{2}$. Although we did not use excess of 1-3 to avoid the formation of compounds from their homo-metathesis, some of them were obtained and remained in the $\mathrm{MeOH}$ solution. The gray precipitates were finally purified by column chromatography affording the $o$-carborane-containing dyads M2, M3, and M4 as white solids in 54, 50, and 49\% yield, respectively.

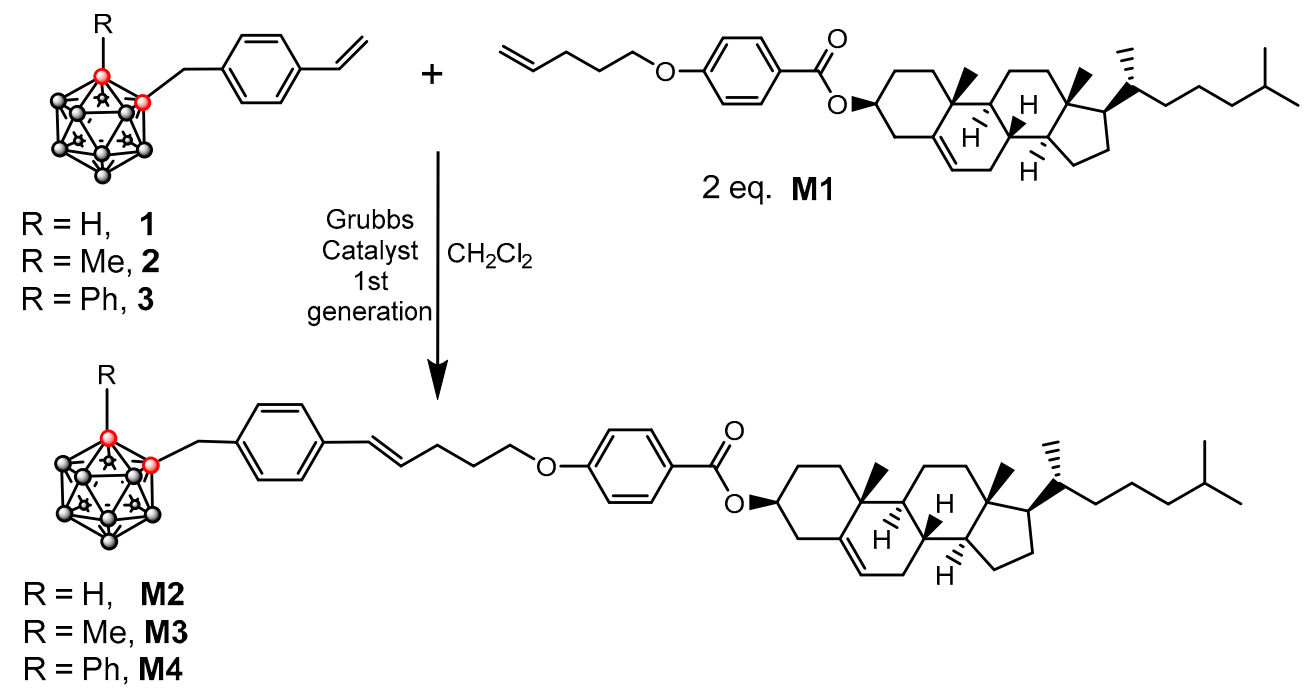

Scheme 1. Synthesis of cholesteryl-o-carborane dyads M2-M4.

In order to understand the influence of the $o$-carborane cluster and its substituent bound to the $C_{c}$ atom on the mesogenic behavior of M2-M4, a carborane-free compound M5 was also synthesized by cross-metathesis of pure styrene with the mesogen M1 (Scheme 2). We used the same conditions as those for M2-M4 with a large excess of styrene due to the ease of the styrene to give the compound from homo-metathesis. M5 was isolated as a white solid in $82 \%$ yield after purification by column chromatography. 


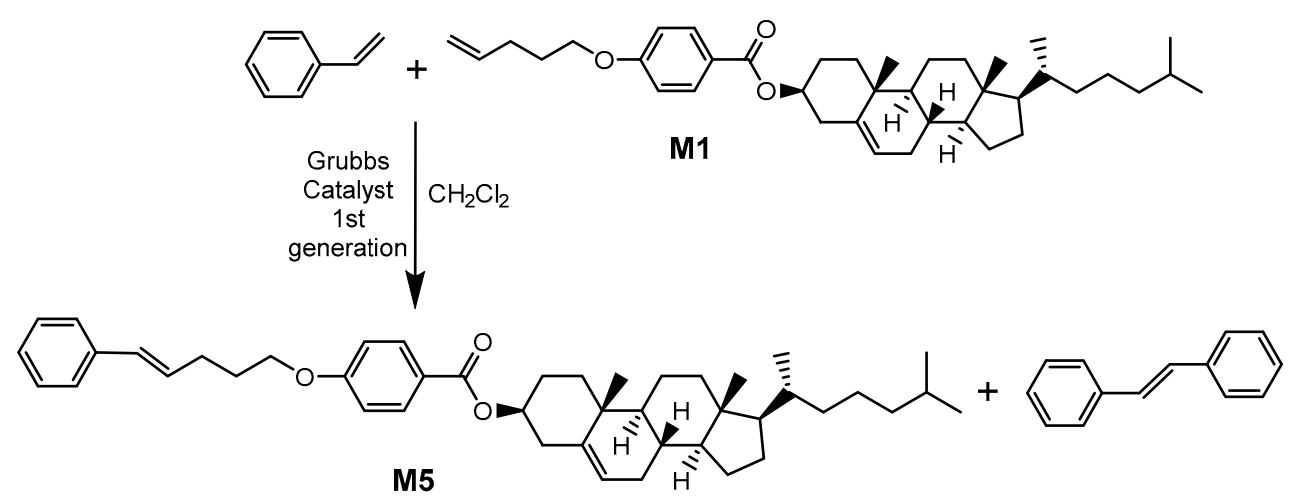

Scheme 2. Synthesis of carborane-free cholesterol derivative M5.

Complete cross-metathesis between $\mathbf{M 1}$ with styrenyl-o-carborane derivatives 1-3 or styrene afforded M2-M5, which was confirmed by standard spectroscopy techniques such as FT-IR, ${ }^{11} \mathrm{~B},{ }^{1} \mathrm{H}$, and ${ }^{13} \mathrm{C}$ NMR, MALDI-TOF mass spectroscopy and elemental analysis. A detailed description of the characterization is included in the Supporting Information. In addition, suitable single crystals of M2, M3, and M5 were analyzed by X-ray diffraction.

\subsection{X-Ray Crystal Structures of $\mathbf{M} 2, \mathbf{M} 3$, and $\mathbf{M} 5$}

Single crystals of $\mathbf{M} 2, \mathbf{M} 3$, and $\mathbf{M} 5$ suitable for X-ray diffraction analysis were obtained by slow evaporation of $\mathrm{CH}_{2} \mathrm{Cl}_{2}$ (M2-3) or toluene (M5) solutions and found suitable for X-ray diffraction analysis. The molecular structures of M2, M3, and M5 are shown in Figures 1 and 2. The main cell crystal parameters can be found in Table S1. A list of selected data and bonding parameters can also be found in the Supporting Information (Tables S2-S4).

(A)

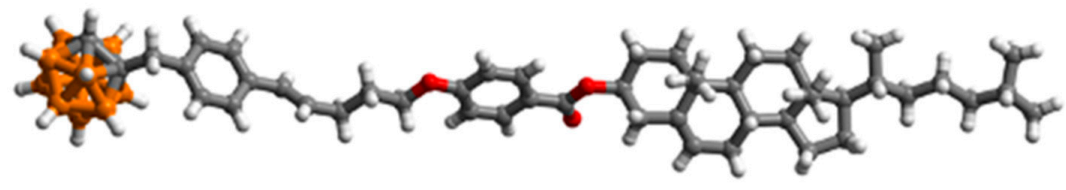

(B)

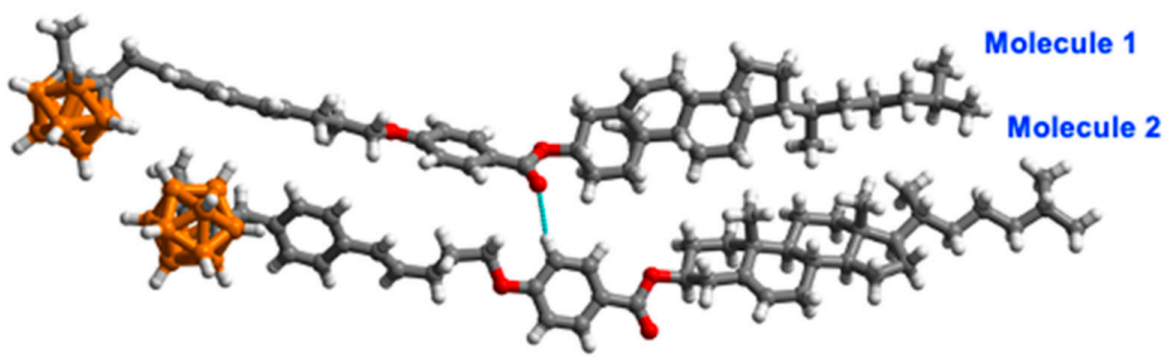

Figure 1. View of independent molecules in the unit cell of M2 (A) and M3 (B). Intermolecular contacts are shown as dotted blue lines. Color codes: $\mathrm{H}$ white; $\mathrm{C}$ gray; $\mathrm{O}$ red; $\mathrm{B}$ orange.

Whereas both $o$-carborane-containing dyads $\mathbf{M} 2$ and $\mathbf{M} 3$ crystallized in the monoclinic and non-centrosymmetric $P 2_{1}$ space group, the styrene derivative $\mathbf{M} 5$ crystallized in the triclinic $P 1$ space group. As shown in Figures 1 and 2 and Figures S16 and S17, unit cells for the compounds showed one, two, or four molecules of M2, M3, and M5, respectively. The shape of the molecules was similar, although slightly different geometries can be observed in M3 (Figure 1) and M5 (Figure 2). In particular, the angles between the plane of the benzoate and the steroid ring in $\mathbf{M} 3$ (i.e., for the $\mathrm{C} 2-\mathrm{C} 7$ plane and $\mathrm{C} 24-\mathrm{C} 28$ mean plane) were $69.50(14)^{\circ}$ and $55.15(16)^{\circ}$, respectively, and between the benzoate ring and the $\mathrm{C}_{6} \mathrm{H}_{4}$ ring close to the cluster (i.e., for the $\mathrm{C} 2-\mathrm{C} 7$ plane and $\mathrm{C} 13-\mathrm{C} 18$ plane), they were $25.77(14)^{\circ}$ and 136.64(15), respectively. 


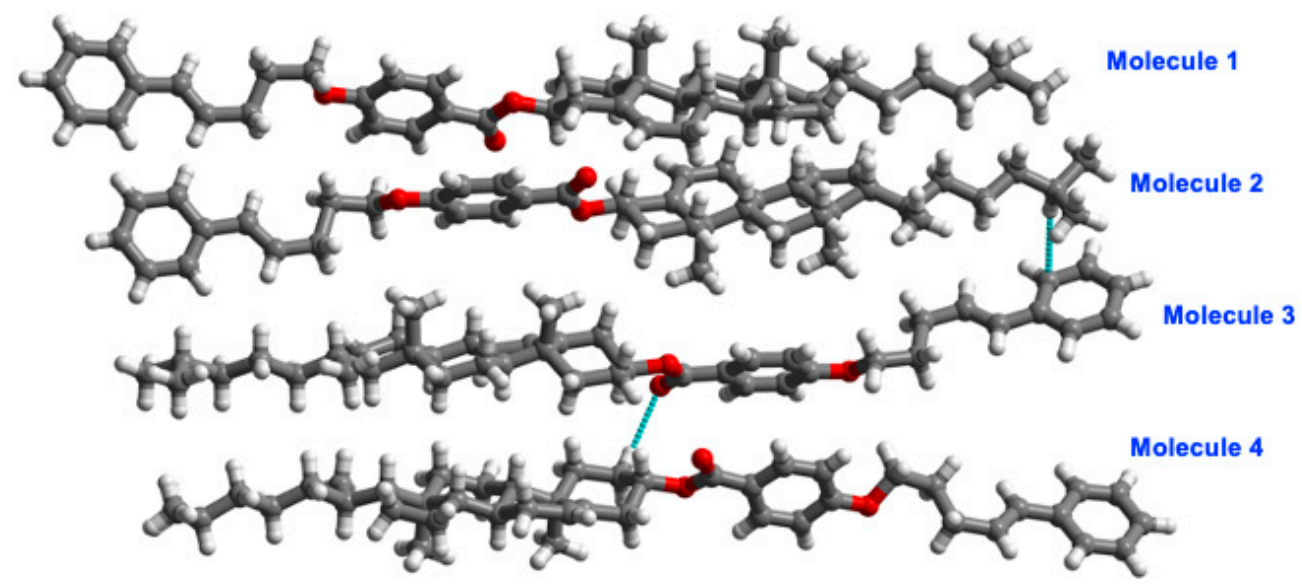

Figure 2. View of independent molecules in the unit cell of M5. Intermolecular contacts are shown as dotted blue lines. Color codes: $\mathrm{H}$ white; $\mathrm{C}$ gray; $\mathrm{O}$ red; $\mathrm{B}$ orange.

In general, the packing motifs in the crystals were similar for all structures. Indeed, the M2, M3, and M5 structures were built from tilted molecules to form layers that were piled giving the observed 3D structures (Figure 3). In all cases, layers were formed by self-assembled molecules oriented parallel to each other (Figure S18). The densities of the 3D structures decreased in the order $\mathbf{M} 5\left(1.152 \mathrm{~g} \mathrm{~cm}^{-3}\right)>\mathbf{M} 3\left(1.135 \mathrm{~g} \mathrm{~cm}^{-3}\right)>$ M2 $\left(1.122 \mathrm{~g} \mathrm{~cm}^{-3}\right)$.

\section{A)}

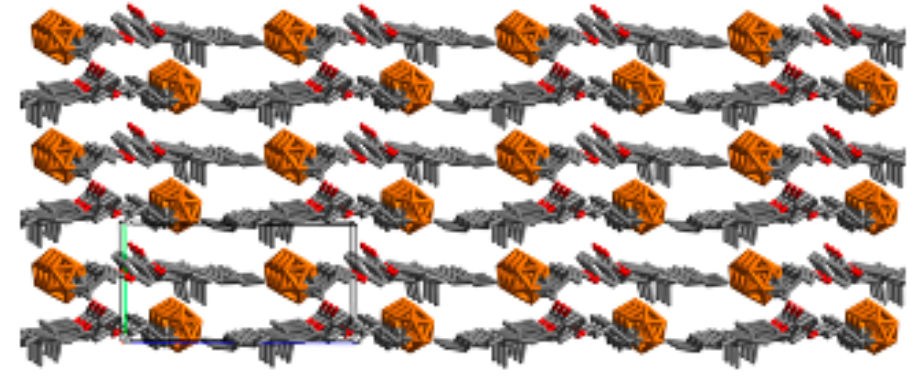

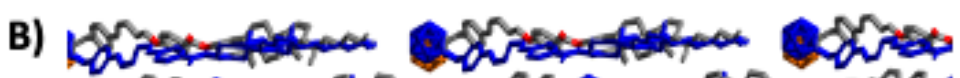

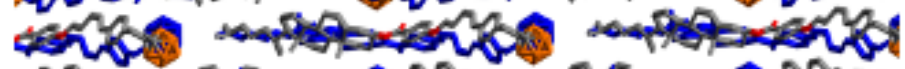

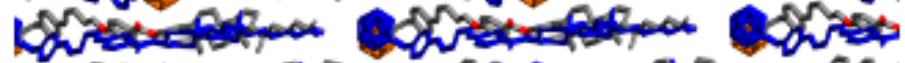
40700 ris

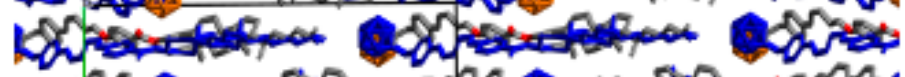

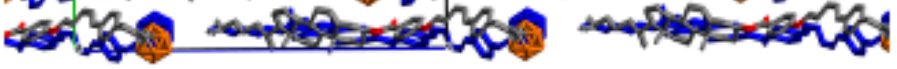

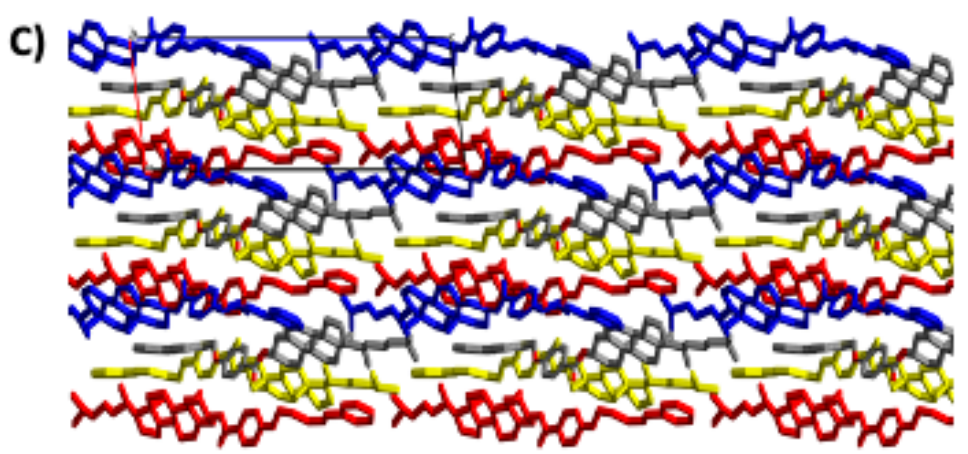

Figure 3. Views of crystal packings of M2 (A), M3 (B), and M5 (C). Independent molecules in the unit cells are colored. $\mathrm{H}$ atoms are omitted for clarity. 
As it is the case in a large majority of mesogens [73-75], and also in the case of most $o$-carborane derivatives [76], the molecules presented here have no strong hydrogen bond donor groups. Therefore, in the obtained crystals, molecules in the layers as well as interactions within the layers are stabilized by weak intermolecular interactions. This is clearly confirmed by the Hirshfeld surface analysis [77] for M2, M3, and M5. The analysis clearly showed the presence of weak $\mathrm{H} \cdots \mathrm{H}$ and $\mathrm{H} \cdots \mathrm{O}$ interactions, with no long sharp spikes characteristic of strong hydrogen bonds and the absence of strong $\pi-\pi$ interactions in the Fingerprint plots (Figure S19) [78]. The relative contributions of different interactions to the Hirshfeld surface were calculated from the Fingerprint plots (Figure 4). From this simple analysis, it can be clearly observed that $\mathrm{H} / \mathrm{H}$ contacts correspond to $78-84 \%$ of the total Hirshfeld surface area for these molecules, which is consistent with the large ratio of external $\mathrm{H}$ to $\mathrm{N}, \mathrm{O}$, or $\mathrm{C}$ atoms. $\mathrm{C} / \mathrm{H}$ contacts comprise around $13-15 \%$ to the total Hirshfeld surface area and $C / C$ (i.e., $\pi-\pi$ ) interactions contribute from $0.8 \%$ in the noncarborane derivative $\mathbf{M} 5$ to an almost negligible percentage in the carborane compounds M2 and M3 (Figure 4).

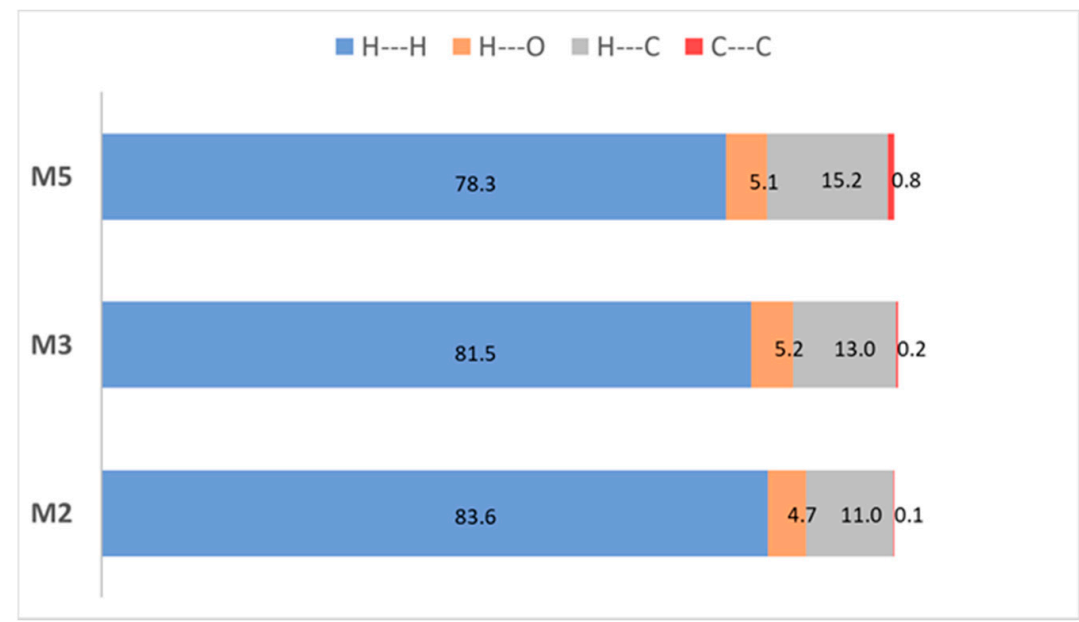

Figure 4. Relative contributions of various intermolecular contacts to the Hirshfeld surface area in all compounds in this study.

Analysis of the data in Figure 4 clearly indicated that the introduction of the $o$ carborane moieties into the mesogen $\mathbf{M 1}$ increases the percentage of $\mathrm{H} \cdots \mathrm{H}$ contacts, while it decreases the percentage of $\mathrm{H} / \mathrm{C}$ and $\mathrm{C} / \mathrm{C}$ contacts. The decrease of the latter two is consistent with the spherical shape of $o$-carborane disrupting the supramolecular contacts of merely flat and aromatic systems (e.g., $\mathrm{C}-\mathrm{H} \cdots \pi$ and $\pi-\pi$ ), and this may affect the mesogenic properties of M2 and M3 when compared to M5 (vide infra). In addition to this, spatial requirements for the carborane cages in these molecules disrupt the efficient packing that, in the absence of these spherical cages, is observed in rod-like molecules such as M5 (Figure 3). This is experimentally observed in the calculated densities of the crystals for M2, M3, and M5 (vide supra).

\subsection{Photophysical Properties}

The photophysical properties of M2-M5, including absorption and emission maxima $\left(\lambda_{\mathrm{abs}}\right.$ and $\left.\lambda_{\mathrm{em}}\right)$, fluorescence quantum yields $\left(\Phi_{\mathrm{f}}\right)$, and Stokes shifts were assessed in $\mathrm{CH}_{2} \mathrm{Cl}_{2}$ (Figure S20 and Table 1). The UV-Vis spectra showed strong maximum absorption peaks at $\lambda_{\mathrm{abs}}=260 \mathrm{~nm}$ for M2-M4 and $\lambda_{\mathrm{abs}}=257 \mathrm{~nm}$ for the non-carborane containing M5, and there were two additional very weak shoulders around 285 and $295 \mathrm{~nm}$ (Figure S20). The absorption peaks were attributed to the $\pi-\pi^{*}$ transitions of the styrenyl group, which is the fluorophore of the molecule, and they appear in the same region as that of the starting compounds 1-3 [42]. Compounds M2, M3, and M5 displayed emission maxima at $\lambda_{\mathrm{em}}=317$ and $319 \mathrm{~nm}$ for $\mathbf{M} 2$ and M3 respectively, whereas M5 exhibited a maximum 
at $315 \mathrm{~nm}$ after excitation at $260 \mathrm{~nm}$ (Figure S20). On the contrary, compound M4 did not show fluorescence emission in solution. These results indicated that the emission properties of M2-M4 were essentially the same as for their precursors 1-3. In previous works, we demonstrated that the photoluminescence properties of precursors 1-3 and their derivatives were influenced by the substituents bound to the $C_{c}$ atom [42], where it was proved that the $\mathrm{Ph}-\mathrm{O}$-carborane moiety acts as an electron-withdrawing group, leading to an efficient quenching of the fluorescence due to a charge transfer process $[42,46]$. This would explain the fluorescence quenching for M4. Fluorescence quantum yield values $\left(\Phi_{\mathrm{f}}\right)$ confirmed that M2 exhibited the highest efficiency (24.8\%), whereas M3 and M5 displayed similar values to each other around $12.2 \%$. It is noteworthy that compounds M2-M4 followed the same trend for their emission properties than their respective precursors 1-3. Noteworthy, the Stokes shift values did not vary significantly within the three luminescent compounds, being all of them close to the region of $7000 \mathrm{~cm}^{-1}$.

Table 1. Photophysical properties of M1-M5.

\begin{tabular}{ccccc}
\hline Compound & $\lambda_{\text {abs }}(\mathbf{n m})$ & $\lambda_{\text {em }}(\mathbf{n m})$ & $\boldsymbol{\Phi}_{\mathbf{f}}(\mathbf{\%})$ & Stokes Shift $\left(\mathbf{c m}^{\left.-\mathbf{1} / \mathbf{1 0}^{\mathbf{3}}\right)}\right.$ \\
\hline M1 & 266 & - & - & - \\
M2 & 260 & 317 & 24.8 & 6.92 \\
M3 & 260 & 319 & 12.2 & 7.11 \\
M4 & 260 & - & - & - \\
M5 & 257 & 315 & 12.1 & 7.16 \\
\hline
\end{tabular}

All spectra were recorded in $\mathrm{CH}_{2} \mathrm{Cl}_{2}$. All samples were prepared to obtain an absorbance of around 0.1 at the excitation wavelength. Quantum yields $\Phi_{\mathrm{f}}$ were calculated using quinine sulfate in a $0.5 \mathrm{M}$ aqueous solution of $\mathrm{H}_{2} \mathrm{SO}_{4}\left(\Phi_{\mathrm{f}}=0.54\right)$ as a standard. Stokes shift $=-10^{*}\left(1 / \lambda_{\mathrm{em}}-1 / \lambda_{\mathrm{abs}}\right)$.

\subsection{Liquid Crystal Properties}

The mesomorphic properties of M1-M5 were investigated by differential scanning calorimetry (DSC) and polarized optical microscopy (POM). The DSC thermograms of M2M5 are shown in Figures S21-S24, and the transition temperatures are listed in Table 2. Selected optical textures determined by POM are presented in Figure 5. The cross-metathesis reaction between the cholesteryl benzoate and the styrenyl-o-carborane derivatives produced only the trans-regioisomer, which is the preferred configuration to induce liquid crystallinity. The $o$-carborane derivative $\mathbf{M} 3(\mathrm{R}=\mathrm{Me})$ is the one that has the most attractive mesomorphic behavior. On cooling from the isotropic state, POM showed the presence of the rare blue phase over a very narrow temperature range $\left(\approx 0.1^{\circ} \mathrm{C}\right)$, which was identified by the mosaic texture (Figure 5b) with very low birefringence [79]. On further cooling, it was followed by the $\mathrm{N}^{*}$ phase, which was identified by the Grandjean planar texture typical of the $\mathrm{N}^{*}$ phase (Figure $5 \mathrm{a}$ ). The blue phase could not be observed in the DSC thermogram, but the thermogram showed clearly the enantiotropic nature of the $\mathrm{N}^{*}$ phase. Pleasingly, mesogens $\mathbf{M} 2(\mathrm{R}=\mathrm{H})$ and $\mathbf{M} 3(\mathrm{R}=\mathrm{Me})$ also displayed the $\mathrm{N}^{*}$ phase, indicating that the $N^{*}$ phase of the cholesterol substituent was preserved upon attachment to the styrenyl-o-carborane cluster. The $\mathrm{N}^{*}$ mesophase of $\mathbf{M 3}$ is enantiotropic in nature (Figure 5a), whereas for $\mathbf{M} 2$, it is a monotropic $\mathrm{N}^{*}$ phase. It is important to note that $\mathbf{M} 2$ showed considerable supercooling of the transition from the isotropic state to the $\mathrm{N}^{*}$ phase, as observed by DSC and POM. The alkenyl cholesteryl benzoate precursor M1 showed a wide temperature range $\mathrm{N}^{*}$, from $131.4^{\circ} \mathrm{C}$ (crystalline state) to $238{ }^{\circ} \mathrm{C}$ (isotropic liquid). The model compound M5 showed the enantiotropic $\mathrm{N}^{*}$ phase over a range $\approx 70{ }^{\circ} \mathrm{C}$, with a clearing point at $224^{\circ} \mathrm{C}$ (Figure 5d), which is at a lower temperature than $\mathbf{M 1}\left(238^{\circ} \mathrm{C}\right)$, indicating the slightly lower thermal stability of the mesophase in comparison with M1 (Table 2). Interestingly, neither M1 nor M5 showed blue phase, suggesting that the $o$-carborane cluster plays a role in stabilizing the intermolecular interactions needed to support the blue phase. Comparison of the transition temperatures showed that the $o$-carborane-containing dyads M2-M4 have lower isotropization temperatures than M5 (Table 2). This comparison 
suggested that the presence of the spherical $o$-carborane cluster disrupts significantly the intermolecular interactions of the cholesteryl benzoate cores needed to induce the mesophase. The higher isotropization temperature of $\mathbf{M} 2$ in comparison with $\mathbf{M} 3$ indicated stronger intermolecular interactions in $\mathbf{M} 2(\mathrm{R}=\mathrm{H})$ than in $\mathbf{M} 3(\mathrm{R}=\mathrm{Me})$. The introduction of an Me group at the $o$-carborane cluster adds steric hindrance and makes space filling more difficult, resulting in a lower clearing point. This different mesogenic behavior between M2 and M3 could be rationalized, taking into account the differences between the solid state at room temperature and the liquid crystalline state, if we consider that the number of $\mathrm{H} \cdots \mathrm{H}$ contacts in the 3D crystal packing of $\mathbf{M} 2$ is higher than in $\mathbf{M} 3$ confirmed by the Hirshfeld surface analysis (vide supra). In contrast, both mesophase range and stability of M5, without the $o$-carborane moiety, are higher than those for M2 and M3. A similar volume effect has been observed when carbocyclic moieties are used as end-groups in certain mesogens [80]. This might be related to the disrupting effect of the $o$-carborane cluster on the $\mathrm{N}^{*}$ phase. On the other hand, $o$-carborane derivative $\mathrm{M} 4(\mathrm{R}=\mathrm{Ph})$ did not show liquid crystallinity, only a series of crystal forms, despite the presence of the strongly nematogen substituent. In this case, the presence of the phenyl group at the $o$-carborane cluster led to a largely bent geometry that disrupts any intermolecular interactions of the cholesterol rigid core needed to promote mesogenic behavior. This is supported by the melting point of M4, which was the lowest of the three cholesteryl-o-carborane derivatives.

Table 2. Phase transition temperatures $\left({ }^{\circ} \mathrm{C}\right)$ and corresponding enthalpy values $\left(\mathrm{J} \mathrm{mol}^{-1}\right.$, in square brackets) obtained from differential scanning calorimetry (DSC) second heating cycles for compounds M2-M5.

\begin{tabular}{cc}
\hline Compound & Phase Transition Temperatures $\left({ }^{\circ} \mathbf{C}\right)$ and Enthalpy Values $\left(\mathbf{J} \cdot \mathbf{m o l}^{-\mathbf{1}}\right)$ \\
\hline M1 & $\mathrm{Cr} 131.4[27.3] \mathrm{N}^{*} 238.6$ [1.3] Iso liq. \\
M2 & $\mathrm{g} 53.1[2.0]\left(\mathrm{N}^{*} 134.9[-10.1]\right) \mathrm{Cr}_{2} 181.7$ [-2.9] Iso liq. \\
M3 & $\mathrm{g} 47.9[2.1] \mathrm{Cr}_{1} 87.1[-13.2] \mathrm{Cr}_{2} 161.6[22.0] \mathrm{N}^{*} 176.2$ [2.1] (BP) Iso liq. \\
M4 & $\mathrm{g} 22.6[2.7] \mathrm{Cr}_{1} 86.2[-1.6] \mathrm{Cr}_{2} 151.9$ [29.3] Iso liq. \\
M5 & $\mathrm{Cr} 150.2[47.8] \mathrm{N}^{*} 224.2$ [3.7] Iso liq. \\
\hline
\end{tabular}

$\mathrm{N}^{*}$ : chiral nematic phase.
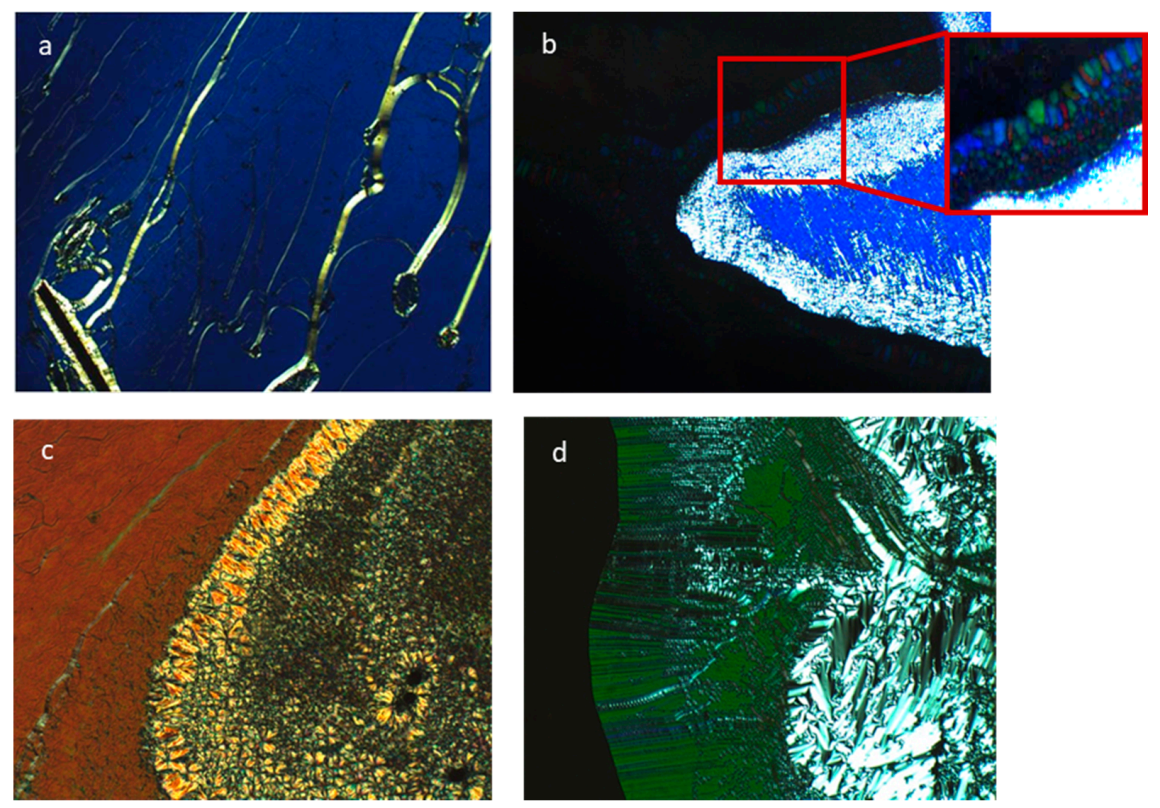

Figure 5. (a) Optical texture of $\mathrm{M} 3$ in the $\mathrm{N}^{*}$ phase at $162.2^{\circ} \mathrm{C}$. (b) Polarized optical microscopy (POM) image of the blue phase of M3. (c) POM image of $\mathbf{M} 2$ at $119.0^{\circ} \mathrm{C}$ on cooling from the isotropic liquid, showing the $\mathrm{N}^{*}$ and crystal phases. (d) POM image of $\mathrm{M} 5$ at $186.2{ }^{\circ} \mathrm{C}$ during the cooling cycle showing the $\mathrm{N}^{*}$ phase. 
Remarkably, these results indicated that the mesomorphic properties of cholesteryl-ocarborane dyads M2-M4 could be modulated by modifying the substituent at the adjacent $\mathrm{C}_{\mathrm{c}}$ atom. Non-substituted (M2) and Me-substituted M3 displayed liquid crystals properties, whereas M4 bearing a Ph group did not show liquid crystallinity. This suggested that the $o$-carborane is a suitable platform for liquid crystals and also may enable tuning of the liquid crystals properties of an attached mesogen group.

\section{Materials and Methods}

\subsection{Materials}

All reactions were performed under an atmosphere of argon employing standard Schlenk techniques. Anhydrous dichloromethane was purchased from Aldrich and used as received. 1- $\left[\mathrm{CH}_{2} \mathrm{C}_{6} \mathrm{H}_{4}-4^{\prime}-\left(\mathrm{CH}=\mathrm{CH}_{2}\right)\right]-2-\mathrm{H}-1,2-$ closo- $\mathrm{C}_{2} \mathrm{~B}_{10} \mathrm{H}_{10}(\mathbf{1}), 1-\left[\mathrm{CH}_{2} \mathrm{C}_{6} \mathrm{H}_{4}-4^{\prime}-\left(\mathrm{CH}=\mathrm{CH}_{2}\right)\right]-$ 2- $\mathrm{CH}_{3}-1,2-$ closo- $\mathrm{C}_{2} \mathrm{~B}_{10} \mathrm{H}_{10}(2)$, and 1- $\left[\mathrm{CH}_{2} \mathrm{C}_{6} \mathrm{H}_{4}-4^{\prime}-\left(\mathrm{CH}=\mathrm{CH}_{2}\right)\right]-2-\mathrm{C}_{6} \mathrm{H}_{5}-1,2-$ closo- $\mathrm{C}_{2} \mathrm{~B}_{10} \mathrm{H}_{10}$ (3) were obtained as described in the literature [42]. M1 was prepared according to the literature process [72]. Reagent grade styrene and first generation Grubbs catalyst were purchased from Aldrich (St. Louis, MO, USA) and used as received. Solvents and all other reagents were purchased from Aldrich and used as received. Reactions were monitored by thin layer chromatography (TLC) using an appropriate solvent system. Silica-coated aluminium TLC plates used were purchased from Merck, Kenilworth, NJ, USA (Kieselgel 60 F-254) and visualized using either UV light (254 nm and $365 \mathrm{~nm}$ ), or by oxidation with either iodine or aqueous potassium permanganate solution.

\subsection{Instrumentation}

Infrared spectra were measured on a Perkin-Elmer Spectrum 400 FT-IR/FT-FIR (Waltham, MA, USA) and Shimadzu IR Prestige-21 (Kyoto, Japan) with Specac Golden Gate diamond ATR IR insert (Orpington, UK). ${ }^{1} \mathrm{H}$ NMR $(300.13 \mathrm{MHz}$ and $400 \mathrm{MHz}$ ) and ${ }^{13} \mathrm{C}\left\{{ }^{1} \mathrm{H}\right\}$ NMR spectra $(75.47 \mathrm{MHz}, 100.5 \mathrm{MHz})$ were obtained using Varian Unity Inova $400 \mathrm{MHz}$ (Palo Alto, CA, USA), JEOL ECX 400 MHz (Akishima, Tokyo, Japan) and Bruker ARX 300 spectrometers (Billerica, MA, USA). The ${ }^{11} \mathrm{~B}\left\{{ }^{1} \mathrm{H}\right\}$ NMR spectra $(96.29 \mathrm{MHz})$ were run on a Bruker ARX 300 spectrometer. All experiments were made with concentrations between 15 and $20 \mathrm{mg} / \mathrm{mL}$ at $25^{\circ} \mathrm{C}$. Chemical shifts $(\mathrm{ppm})$ are relative to $\mathrm{Si}\left(\mathrm{CH}_{3}\right)_{4}$ for ${ }^{1} \mathrm{H}$ (of residual proton; $\delta 7.25 \mathrm{ppm}$ ) and ${ }^{13} \mathrm{C}\left\{{ }^{1} \mathrm{H}\right\} \mathrm{NMR}\left(\delta 77.23 \mathrm{ppm}\right.$ signal) in $\mathrm{CDCl}_{3}$. Chemical shift values for ${ }^{11} \mathrm{~B}\left\{{ }^{1} \mathrm{H}\right\} \mathrm{NMR}$ spectra were referenced to external $\mathrm{BF}_{3} \cdot \mathrm{OEt}_{2}$. Chemical shifts are reported in units of parts per million downfield from the reference, and all coupling constants are reported in Hz. Mass spectra were recorded on a Bruker Solarix FT-ICR (MALDI TOF/TOFTM spectra). UV/Vis spectra were measured on a Perkin Elmer Lambda 900 and Shimadzu UV-1700 Pharmaspec spectrophotometers using $1.0 \mathrm{~cm}$ cuvettes. Fluorescence emission spectra were recorded in a Perkin-Elmer LS-45 (230 V) Fluorescence spectrometer. Samples were prepared in spectroscopic grade solvents and adjusted to a response within the linear range. No fluorescent contaminants were detected on excitation in the wavelength region of experimental interest. CHN Elemental analyses were performed using an Exeter Analytical Inc. CE440 analyzer (North Chelmsford, MA, USA).

\subsection{X-ray Diffraction}

Diffraction data were collected at $110 \mathrm{~K}$ on an Oxford Diffraction SuperNova diffractometer (Abingdon, Oxfordshire, UK) with Mo-K $\mathrm{K}_{\alpha}$ radiation $(\lambda=0.71073 \AA$ ) using an EOS CCD camera (Canon, Tokyo, Japan). The crystal was cooled with an Oxford Instruments Cryojet. Diffractometer control, data collection, initial unit cell determination, frame integration, and unit-cell refinement was carried out with "Crysalis" [81]. Face-indexed absorption corrections were applied using spherical harmonics, implemented in a SCALE3 ABSPACK scaling algorithm [81]. OLEX2c was used for overall structure solution, refinement, and preparation of computer graphics and publication data. Within OLEX2, the algorithm used for structure solution was direct methods [82] for M2 and M3 and charge-flipping [83] for M5. Refinement by full-matrix least-squares used the SHELXL [82] 
algorithm within OLEX2 [84]. All non-hydrogen atoms were refined anisotropically. Hydrogen atoms were placed using a "riding model" and included in the refinement at calculated positions.

In the case of compound M5, the differences among molecules in the unit cell differ in the orientation of the steroid system, the benzoate, and the terminal phenyl ring. For the four molecules, the angle between the plane of the benzoate and the steroid ring was $\left(50.71(12)^{\circ}, 68.7(3)^{\circ}, 54.87(13)^{\circ}\right.$, and $40.88(12)^{\circ}$, respectively; the angle between the benzoate ring and the phenyl ring was $112.52(12)^{\circ}, 93.8(3)^{\circ}, 67.33(12)^{\circ}$, and $80.6(5)^{\circ}$, respectively. Two of the molecules exhibited disorder. For one, the benzoate ring and the para- $\mathrm{OCH}_{2}$ was modeled in two positions with refined occupations of 0.684:0.316(4), whilst for the other, the phenyl was modeled in two positions with refined occupancies of 0.654:0.346(4). When calculating the planes for the angles described above, an average position was used.

\subsection{Phase Identification by Optical and Thermal Methods}

Polarized optical microscopy was performed on a Zeiss Axioskop 40Pol microscope (Oberkochen, Germany) using a Mettler FP82HT hotstage (Columbus, OH, USA) controlled by a Mettler FP90 central processor. Photomicrographs were captured via either an InfinityX-21 digital camera or a Sony NEX 5R mirrorless digital camera (Tokyo, Japan) mounted atop the microscope. Differential scanning calorimetry was performed on a Mettler DSC822e fitted with an autosampler operating with MettlerStar ${ }^{\circledR}$ software and calibrated before use against an indium standard (onset $=156.55 \pm 0.2{ }^{\circ} \mathrm{C}, \Delta \mathrm{H}=28.45 \pm 0.40 \mathrm{Jg}^{-1}$ ) under an atmosphere of dry nitrogen.

\subsection{Synthesis of Mesogens M2-M5}

\subsubsection{Synthesis of $\mathbf{M} 2$}

In a dry-oven $25 \mathrm{~mL}$ schlenk flask, $1-\left[\mathrm{CH}_{2} \mathrm{C}_{6} \mathrm{H}_{4}-4^{\prime}-\left(\mathrm{CH}=\mathrm{CH}_{2}\right)\right]-2-\mathrm{H}-1,2-$ closo- $\mathrm{C}_{2} \mathrm{~B}_{10} \mathrm{H}_{10}$ (1) $(68 \mathrm{mg}, 0.26 \mathrm{mmol}), \mathbf{M 1}(300 \mathrm{mg}, 0.52 \mathrm{mmol})$, and first-generation Grubbs' catalyst (21 mg, $0.026 \mathrm{mmol}$ ) were dissolved in $\mathrm{CH}_{2} \mathrm{Cl}_{2}(10 \mathrm{~mL})$. The solution was stirred and refluxed for $48 \mathrm{~h}$. The reaction was monitored by ${ }^{1} \mathrm{H}$ NMR to the disappearance of the alkene protons of M1. After that, the mixture was cooled down to room temperature, filtered, and the brown solution was quenched by precipitation into $40 \mathrm{~mL}$ of methanol to afford a gray solid. This is filtered and purified by silica gel column chromatography ( $75 \% \mathrm{CH}_{2} \mathrm{Cl}_{2}-25 \%$ hexane), leading to compound $\mathbf{M} 2$ as a pure white solid. Yield: $114 \mathrm{mg}$, $54 \%$. A C $\mathrm{CH}_{2} \mathrm{Cl}_{2}$ solution of $\mathbf{M} 2$ gave crystals suitable for X-ray analysis. ${ }^{1} \mathrm{H} \mathrm{NMR}\left(\mathrm{CDCl}_{3}\right.$, TMS), $\delta(\mathrm{ppm}): 7.97\left(\mathrm{~d},{ }^{3} \mathrm{~J}(\mathrm{H}, \mathrm{H})=8 \mathrm{~Hz}, 2 \mathrm{H}, \mathrm{C}_{6} \mathrm{H}_{4}\right), 7.30\left(\mathrm{~d},{ }^{3} \mathrm{~J}(\mathrm{H}, \mathrm{H})=8 \mathrm{~Hz}, 2 \mathrm{H}, \mathrm{C}_{6} \mathrm{H}_{4}\right)$, $7.05\left(\mathrm{~d},{ }^{3} \mathrm{~J}(\mathrm{H}, \mathrm{H})=8 \mathrm{~Hz}, 2 \mathrm{H}, \mathrm{C}_{6} H_{4}\right), 6.89\left(\mathrm{~d},{ }^{3} \mathrm{~J}(\mathrm{H}, \mathrm{H})=8 \mathrm{~Hz}, 2 \mathrm{H}, \mathrm{C}_{6} \mathrm{H}_{4}\right), 6.40\left(\mathrm{~d},{ }^{3} \mathrm{~J}(\mathrm{H}, \mathrm{H})=\right.$ $\left.16 \mathrm{~Hz}, 1 \mathrm{H}, \mathrm{C}_{6} \mathrm{H}_{4} \mathrm{CH}=\mathrm{CH}\right), 6.26\left(\mathrm{dt}^{3} \mathrm{~J}(\mathrm{H}, \mathrm{H})=16 \mathrm{~Hz},{ }^{3} \mathrm{~J}(\mathrm{H}, \mathrm{H})=8 \mathrm{~Hz}, 1 \mathrm{H}, \mathrm{C}_{6} \mathrm{H}_{4} \mathrm{CH}=\mathrm{CH}\right)$, $5.40\left(\mathrm{~d},{ }^{3} \mathrm{~J}(\mathrm{H}, \mathrm{H})=6 \mathrm{~Hz}, 1 \mathrm{H},\left(\mathrm{C}_{\mathrm{h}}\right) \mathrm{CH}=\mathrm{CH}\right), 4.81\left(\mathrm{~m}, 1 \mathrm{H}, \mathrm{OCH}\left(\mathrm{C}_{\mathrm{h}}\right)\right), 4.05\left(\mathrm{t}, 2 \mathrm{H},{ }^{3} \mathrm{~J}(\mathrm{H}, \mathrm{H})\right.$ $\left.=6 \mathrm{~Hz}, \mathrm{CH}_{2} \mathrm{O}\right), 3.48\left(\mathrm{~s}, 2 \mathrm{H}, \mathrm{C}_{\mathrm{c}}-\mathrm{CH}_{2}\right), 3.19\left(\mathrm{~s}, 1 \mathrm{H}, \mathrm{C}_{\mathrm{c}}-\mathrm{H}\right), 2.42\left(\mathrm{~m}, 4 \mathrm{H}, \mathrm{OCHCH}_{2}\left(\mathrm{C}_{\mathrm{h}}\right)+\right.$ $\left.\mathrm{C}_{6} \mathrm{H}_{4} \mathrm{CH}=\mathrm{CHCH}_{2}\right), 1.05\left(\mathrm{~s}, 3 \mathrm{H}, \mathrm{C}-\mathrm{CH}_{3}\right), 0.91\left(\mathrm{~d},{ }^{3} \mathrm{~J}(\mathrm{H}, \mathrm{H})=6 \mathrm{~Hz}, 3 \mathrm{H}, \mathrm{CHCH}_{3}\right), 0.85(\mathrm{dd}$, $\left.{ }^{3} \mathrm{~J}(\mathrm{H}, \mathrm{H})=6 \mathrm{~Hz},{ }^{3} \mathrm{~J}(\mathrm{H}, \mathrm{H})=3 \mathrm{~Hz}, 6 \mathrm{H}, \mathrm{CH}\left(\mathrm{CH}_{3}\right)_{2}\right), 0.67\left(\mathrm{~s}, 3 \mathrm{H}, \mathrm{C}-\mathrm{CH}_{3}\right) .{ }^{11} \mathrm{~B}\left\{{ }^{1} \mathrm{H}\right\} \mathrm{NMR}$ $\left(\mathrm{CDCl}_{3}, \mathrm{BF}_{3} \cdot \mathrm{Et}_{2} \mathrm{O}\right), \delta(\mathrm{ppm}):-3.33(1 \mathrm{~B}),-6.48(1 \mathrm{~B}),-9.90(2 \mathrm{~B}),-11.54 \mathrm{ppm}(2 \mathrm{~B}),-14.05$ (4B). $\left.{ }^{13} \mathrm{C}^{1}{ }^{1} \mathrm{H}\right\}$ NMR $\left(\mathrm{CDCl}_{3}, \mathrm{TMS}\right), \delta(\mathrm{ppm}): 165.87$ (s, $\left.\mathrm{C}=\mathrm{O}\right), 162.71\left(\mathrm{~s}, \mathrm{C}_{a r}-\mathrm{O}\right), 139.84$ (s, $\left.\mathrm{C}=\mathrm{CH}\left(\mathrm{C}_{\mathrm{h}}\right)\right), 137.84\left(\mathrm{~s}, \mathrm{C}_{6} \mathrm{H}_{4}\right), 132.92\left(\mathrm{~s}, \mathrm{C}_{6} \mathrm{H}_{4}\right), 131.62\left(\mathrm{~s}, \mathrm{C}_{6} \mathrm{H}_{4}\right), 130.79\left(\mathrm{~s}, \mathrm{C}_{6} \mathrm{H}_{4}\right), 130.08(\mathrm{~s}$, $\left.\mathrm{C}_{6} \mathrm{H}_{4} \mathrm{CH}=\mathrm{CH}\right), 129.93\left(\mathrm{~s}, \mathrm{C}_{6} \mathrm{H}_{4} \mathrm{CH}=\mathrm{CH}\right), 126.62\left(\mathrm{~s}, \mathrm{C}_{6} \mathrm{H}_{4}\right), 123.29\left(\mathrm{~s}, \mathrm{C}_{6} \mathrm{H}_{4}\right), 122.78\left(\mathrm{~s}, \mathrm{C}_{6} \mathrm{H}_{4}\right)$, $114.06\left(\mathrm{~s}, \mathrm{C}=\mathrm{CH}\left(\mathrm{C}_{\mathrm{h}}\right)\right), 74.32(\mathrm{~s}, \mathrm{CH}-\mathrm{O}), 67.31\left(\mathrm{~s}, \mathrm{CH}_{2}-\mathrm{O}\right), 56.78\left(\mathrm{~s}, \mathrm{CH}\left(\mathrm{C}_{\mathrm{p}}\right)\right), 56.21\left(\mathrm{~s}, \mathrm{CH}\left(\mathrm{C}_{\mathrm{p}}\right)\right)$, $50.12\left(\mathrm{~s}, \mathrm{CH}\left(\mathrm{C}_{\mathrm{h}}\right)\right), 43.22\left(\mathrm{~s}, \mathrm{CH}\left(\mathrm{C}_{\mathrm{p}}-\mathrm{C}_{\mathrm{h}}\right)\right), 42.41\left(\mathrm{~s}, \mathrm{C}_{\mathrm{c}}-\mathrm{CH}_{2}\right), 39.83\left(\mathrm{~s}, \mathrm{CH}_{2} \mathrm{CH}\left(\mathrm{CH}_{3}\right)_{2}\right), 39.60$ $\left(\mathrm{s}, \mathrm{CH}\left(\mathrm{C}_{\mathrm{h}}\right)\right), 38.38\left(\mathrm{~s}, \mathrm{CH}_{2} \mathrm{C}-\mathrm{O}\right), 37.14\left(\mathrm{~s}, \mathrm{CH}\left(\mathrm{C}_{\mathrm{h}}\right)\right), 36.74\left(\mathrm{~s}, \mathrm{CH}\left(\mathrm{C}_{\mathrm{h}}\right)\right), 36.27\left(\mathrm{~s}, \mathrm{CH}_{3} \mathrm{CHCH}_{2}\right)$, 35.89 (s, $\left.\mathrm{CH}_{3} \mathrm{CHCH}_{2}\right), 32.02\left(\mathrm{~s}, \mathrm{CH}\left(\mathrm{C}_{\mathrm{h}}\right)\right), 31.97\left(\mathrm{~s}, \mathrm{CH}\left(\mathrm{C}_{\mathrm{h}}\right)\right), 28.79\left(\mathrm{~s}, \mathrm{CH}=\mathrm{CHCH}_{2} \mathrm{CH}_{2}\right)$, $28.33\left(\mathrm{~s}, \mathrm{CH}\left(\mathrm{C}_{\mathrm{h}}\right)\right), 28.11\left(\mathrm{~s}, \mathrm{CH}\left(\mathrm{C}_{\mathrm{p}}\right)\right), 28.03\left(\mathrm{~s}, \mathrm{CH}-\left(\mathrm{CH}_{3}\right)_{2}\right), 24.38\left(\mathrm{~s}, \mathrm{CH}_{2}\left(\mathrm{C}_{\mathrm{p}}\right)\right), 26.90(\mathrm{~s}$, $\left.\mathrm{CH}\left(\mathrm{C}_{\mathrm{h}}\right)\right), 24.38\left(\mathrm{~s}, \mathrm{CH}_{2} \mathrm{CH}_{2} \mathrm{CH}-\left(\mathrm{CH}_{3}\right)_{2}\right), 23.92\left(\mathrm{~s}, \mathrm{CH}\left(\mathrm{C}_{\mathrm{h}}\right)\right), 22.92\left(\mathrm{~s}, \mathrm{CH}-\left(\mathrm{CH}_{3}\right)_{2}\right), 22.66$ (s, $\left.\mathrm{CH}-\left(\mathrm{CH}_{3}\right)_{2}\right), 21.13\left(\mathrm{~s}, \mathrm{CH}\left(\mathrm{C}_{\mathrm{h}}\right)\right), 19.48\left(\mathrm{~s}, \mathrm{CH}-\mathrm{CH}_{3}\right), 18.81\left(\mathrm{~s}, \mathrm{CH}-\mathrm{CH}_{3}\right), 11.95 \mathrm{ppm}(\mathrm{s}$, $\mathrm{CH}-\mathrm{CH}_{3}$ ). ATR ( $\mathrm{cm}^{-1}$ ): 2939 (br s, C-H st), 2576 (br s, B-H st), 1697 (s, C=O st), 1604 (m, 
$\mathrm{C}=\mathrm{C}$ st). MALDI-TOF-MS ( $m / z)$ : Calcd: 808.66. Found: $846.55\left[\mathrm{M}+\mathrm{K}^{+}\right]$. Anal. Calcd. for $\mathrm{C}_{48} \mathrm{H}_{74} \mathrm{~B}_{10} \mathrm{O}_{3}$ : C, 71.42; $\mathrm{H}, 9.24$. Found: $\mathrm{C}, 71.58 ; \mathrm{H}, 9.15$.

\subsubsection{Synthesis of $\mathbf{M} 3$}

Compound $\mathbf{M} 3$ was synthesized using the same procedure as for $\mathbf{M} 2$, but using 1$\left[\mathrm{CH}_{2} \mathrm{C}_{6} \mathrm{H}_{4}-4^{\prime}-\left(\mathrm{CH}=\mathrm{CH}_{2}\right)\right]-2-\mathrm{CH}_{3}-1,2-$ closo- $\mathrm{C}_{2} \mathrm{~B}_{10} \mathrm{H}_{10}$ (2) $(23 \mathrm{mg}, 0.08 \mathrm{mmol}), \mathbf{M 1}(100 \mathrm{mg}$, $0.17 \mathrm{mmol}$ ) and first-generation Grubbs catalyst $(7 \mathrm{mg}, 0.008 \mathrm{mmol})$ in $10 \mathrm{~mL}$ of $\mathrm{CH}_{2} \mathrm{Cl}_{2}$. After work-up, M3 was obtained as a pure white solid. Yield: $38 \mathrm{mg}, 50 \% . \mathrm{A} \mathrm{CH}_{2} \mathrm{Cl}_{2}$ solution of $\mathbf{M} 3$ gave crystals suitable for X-ray analysis. ${ }^{1} \mathrm{H}$ NMR $\left(\mathrm{CDCl}_{3}, \mathrm{TMS}\right), \delta(\mathrm{ppm})$ : $7.97\left(\mathrm{~d},{ }^{3} \mathrm{~J}(\mathrm{H}, \mathrm{H})=8 \mathrm{~Hz}, 2 \mathrm{H}, \mathrm{C}_{6} \mathrm{H}_{4}\right), 7.30\left(\mathrm{~d},{ }^{3} \mathrm{~J}(\mathrm{H}, \mathrm{H})=8 \mathrm{~Hz}, 2 \mathrm{H}, \mathrm{C}_{6} \mathrm{H}_{4}\right), 7.10\left(\mathrm{~d},{ }^{3} \mathrm{~J}(\mathrm{H}, \mathrm{H})\right.$ $\left.=8 \mathrm{~Hz}, 2 \mathrm{H}, \mathrm{C}_{6} \mathrm{H}_{4}\right), 6.90\left(\mathrm{~d},{ }^{3} \mathrm{~J}(\mathrm{H}, \mathrm{H})=8 \mathrm{~Hz}, 2 \mathrm{H}, \mathrm{C}_{6} H_{4}\right), 6.41\left(\mathrm{~d},{ }^{3} \mathrm{~J}(\mathrm{H}, \mathrm{H})=16 \mathrm{~Hz}, 1 \mathrm{H}\right.$, $\left.\mathrm{C}_{6} \mathrm{H}_{4} \mathrm{CH}=\mathrm{CH}\right), 6.25\left(\mathrm{dt},{ }^{3} \mathrm{~J}(\mathrm{H}, \mathrm{H})=16 \mathrm{~Hz},{ }^{3} \mathrm{~J}(\mathrm{H}, \mathrm{H})=6 \mathrm{~Hz}, 1 \mathrm{H}, \mathrm{C}_{6} \mathrm{H}_{4} \mathrm{CH}=\mathrm{CH}\right), 5.40(\mathrm{~d}$, $\left.{ }^{3} \mathrm{~J}(\mathrm{H}, \mathrm{H})=6 \mathrm{~Hz}, 1 \mathrm{H},\left(\mathrm{C}_{\mathrm{h}}\right) \mathrm{CH}=\mathrm{CH}\right), 4.81\left(\mathrm{~m}, 1 \mathrm{H}, \mathrm{OCH}\left(\mathrm{C}_{\mathrm{h}}\right)\right), 4.05\left(\mathrm{t}, 2 \mathrm{H},{ }^{3} \mathrm{~J}(\mathrm{H}, \mathrm{H})=6 \mathrm{~Hz}\right.$, $\left.\mathrm{CH}_{2} \mathrm{O}\right), 3.42\left(\mathrm{~s}, 2 \mathrm{H}, \mathrm{C}_{\mathrm{c}}-\mathrm{CH}_{2}\right), 2.42\left(\mathrm{~m}, 4 \mathrm{H}, \mathrm{OCHCH}_{2}\left(\mathrm{C}_{\mathrm{h}}\right)+\mathrm{C}_{6} \mathrm{H}_{4} \mathrm{CH}=\mathrm{CHCH}_{2}\right), 2.14(\mathrm{~s}, 3 \mathrm{H}$, $\left.\mathrm{C}_{\mathrm{c}}-\mathrm{CH}_{3}\right), 1.06\left(\mathrm{~s}, 3 \mathrm{H}, \mathrm{C}-\mathrm{CH}_{3}\right), 0.91\left(\mathrm{~d},{ }^{3} \mathrm{~J}(\mathrm{H}, \mathrm{H})=6 \mathrm{~Hz}, 3 \mathrm{H}, \mathrm{CHCH}_{3}\right), 0.85\left(\mathrm{dd},{ }^{3} \mathrm{~J}(\mathrm{H}, \mathrm{H})=6\right.$ $\left.\mathrm{Hz},{ }^{3} \mathrm{~J}(\mathrm{H}, \mathrm{H})=3 \mathrm{~Hz}, 6 \mathrm{H}, \mathrm{CH}\left(\mathrm{CH}_{3}\right)_{2}\right), 0.67\left(\mathrm{~s}, 3 \mathrm{H}, \mathrm{C}-\mathrm{CH}_{3}\right) .{ }^{11} \mathrm{~B}\left\{{ }^{1} \mathrm{H}\right\} \mathrm{NMR}\left(\mathrm{CDCl}_{3}, \mathrm{BF}_{3} \cdot \mathrm{Et}_{2} \mathrm{O}\right)$, $\delta$ (ppm): $-4.99(1 \mathrm{~B}),-6.55(1 \mathrm{~B}),-10.65(4 \mathrm{~B}),-11.29 \mathrm{ppm}(4 \mathrm{~B}) .{ }^{13} \mathrm{C}\left\{{ }^{1} \mathrm{H}\right\} \mathrm{NMR}\left(\mathrm{CDCl}_{3}, \mathrm{TMS}\right)$, $\delta(\mathrm{ppm}): 165.84(\mathrm{~s}, \mathrm{C}=\mathrm{O}), 162.73\left(\mathrm{~s}, \mathrm{C}_{a r}-\mathrm{O}\right), 139.86\left(\mathrm{~s}, \mathrm{C}=\mathrm{CH}\left(\mathrm{C}_{\mathrm{h}}\right)\right), 137.38\left(\mathrm{~s}, \mathrm{C}_{6} \mathrm{H}_{4}\right), 133.75$ (s, $\left.\mathrm{C}_{6} \mathrm{H}_{4}\right), 131.60\left(\mathrm{~s}, \mathrm{C}_{6} \mathrm{H}_{4}\right), 130.56\left(\mathrm{~s}, \mathrm{C}_{6} \mathrm{H}_{4}\right), 130.35\left(\mathrm{~s}, \mathrm{C}_{6} \mathrm{H}_{4} \mathrm{CH}=\mathrm{CH}\right), 130.11\left(\mathrm{~s}, \mathrm{C}_{6} \mathrm{H}_{4} \mathrm{CH}=\mathrm{CH}\right)$, $126.20\left(\mathrm{~s}, \mathrm{C}_{6} \mathrm{H}_{4}\right), 122.71\left(\mathrm{~s}, \mathrm{C}_{6} \mathrm{H}_{4}\right), 114.01\left(\mathrm{~s}, \mathrm{C}=\mathrm{CH}\left(\mathrm{C}_{\mathrm{h}}\right)\right), 74.27(\mathrm{~s}, \mathrm{CH}-\mathrm{O}), 67.36\left(\mathrm{~s}, \mathrm{CH}_{2}-\mathrm{O}\right)$, $56.78\left(\mathrm{~s}, \mathrm{CH}\left(\mathrm{C}_{\mathrm{p}}\right)\right), 56.21\left(\mathrm{~s}, \mathrm{CH}\left(\mathrm{C}_{\mathrm{p}}\right)\right), 50.12\left(\mathrm{~s}, \mathrm{CH}\left(\mathrm{C}_{\mathrm{h}}\right)\right), 42.40\left(\mathrm{~s}, \mathrm{CH}\left(\mathrm{C}_{\mathrm{p}}-\mathrm{C}_{\mathrm{h}}\right)\right), 41.01(\mathrm{~s}$, $\left.\mathrm{C}_{\mathrm{c}}-\mathrm{CH}_{2}\right), 39.82\left(\mathrm{~s}, \mathrm{CH}_{2} \mathrm{CH}\left(\mathrm{CH}_{3}\right)_{2}\right), 39.60\left(\mathrm{~s}, \mathrm{CH}\left(\mathrm{C}_{\mathrm{h}}\right)\right), 38.38$ (s, $\left.\mathrm{CH}_{2} \mathrm{C}-\mathrm{O}\right), 37.14\left(\mathrm{~s}, \mathrm{CH}\left(\mathrm{C}_{\mathrm{h}}\right)\right)$, $36.74\left(\mathrm{~s}, \mathrm{CH}\left(\mathrm{C}_{\mathrm{h}}\right)\right), 36.27\left(\mathrm{~s}, \mathrm{CH}_{3} \mathrm{CHCH}_{2}\right), 35.89\left(\mathrm{~s}, \mathrm{CH}_{3} \mathrm{CHCH}_{2}\right), 32.02\left(\mathrm{~s}, \mathrm{CH}\left(\mathrm{C}_{\mathrm{h}}\right)\right), 31.97$ (s, $\left.\mathrm{CH}\left(\mathrm{C}_{\mathrm{h}}\right)\right), 29.47\left(\mathrm{~s}, \mathrm{CH}=\mathrm{CHCH}_{2} \mathrm{CH}_{2}\right), 28.82\left(\mathrm{~s}, \mathrm{CH}=\mathrm{CHCH}_{2} \mathrm{CH}_{2}\right), 28.33\left(\mathrm{~s}, \mathrm{CH}\left(\mathrm{C}_{\mathrm{h}}\right)\right), 28.11$ (s, $\left.\mathrm{CH}\left(\mathrm{C}_{\mathrm{p}}\right)\right), 28.03\left(\mathrm{~s}, \mathrm{CH}-\left(\mathrm{CH}_{3}\right)_{2}\right), 24.38\left(\mathrm{~s}, \mathrm{CH}_{2}\left(\mathrm{C}_{\mathrm{p}}\right)\right), 23.91\left(\mathrm{~s}, \mathrm{CH}_{2} \mathrm{CH}_{2} \mathrm{CH}-\left(\mathrm{CH}_{3}\right)_{2}\right), 23.78$ (s, $\left.\mathrm{C}_{\mathrm{c}}-\mathrm{CH}_{3}\right), 22.92\left(\mathrm{~s}, \mathrm{CH}-\left(\mathrm{CH}_{3}\right)_{2}\right), 22.66\left(\mathrm{~s}, \mathrm{CH}-\left(\mathrm{CH}_{3}\right)_{2}\right), 21.13\left(\mathrm{~s}, \mathrm{CH}\left(\mathrm{C}_{\mathrm{h}}\right)\right), 19.48\left(\mathrm{~s}, \mathrm{CH}-\mathrm{CH}_{3}\right)$, $18.81\left(\mathrm{~s}, \mathrm{CH}-\mathrm{CH}_{3}\right), 11.95$ ppm (s, CH-CH$) . A T R\left(\mathrm{~cm}^{-1}\right)$ : 2931 (br s, C-H st), 2584 (br s, B-H st), 1705 ( $\mathrm{s}, \mathrm{C}=\mathrm{O}$ st), 1604 ( $\mathrm{m}, \mathrm{C}=\mathrm{C}$ st). MALDI-TOF-MS ( $\mathrm{m} / \mathrm{z}$ ): Calcd: 822.67. Found: $860.56\left[\mathrm{M}+\mathrm{K}^{+}\right.$]. Anal. Calcd. for $\mathrm{C}_{49} \mathrm{H}_{76} \mathrm{~B}_{10} \mathrm{O}_{3}: \mathrm{C}, 71.66 ; \mathrm{H}, 9.33$. Found: $\mathrm{C}, 72.11 ; \mathrm{H}, 9.32$.

\subsubsection{Synthesis of $\mathbf{M} 4$}

Compound $\mathbf{M} 4$ was synthesized using the same procedure as for $\mathbf{M} 2$ and $\mathbf{M} 3$ but using 1-[ $\left[\mathrm{CH}_{2} \mathrm{C}_{6} \mathrm{H}_{4}-4^{\prime}-\left(\mathrm{CH}=\mathrm{CH}_{2}\right)\right]-2-\mathrm{C}_{6} \mathrm{H}_{5}-1,2-$ closo- $\mathrm{C}_{2} \mathrm{~B}_{10} \mathrm{H}_{10}$ (3) $(50 \mathrm{mg}, 0.15 \mathrm{mmol}), \mathbf{M 1}$ (171 mg, $0.30 \mathrm{mmol}$ ) and first-generation Grubbs catalyst (12 mg, $0.015 \mathrm{mmol})$ in $6 \mathrm{~mL}$ of $\mathrm{CH}_{2} \mathrm{Cl}_{2}$. After work-up, M4 was obtained as a pure white solid. Yield: $64 \mathrm{mg}, 49 \% .{ }^{1} \mathrm{H}$ NMR $\left(\mathrm{CDCl}_{3}, \mathrm{TMS}\right), \delta(\mathrm{ppm}): 7.99\left(\mathrm{~d},{ }^{3} \mathrm{~J}(\mathrm{H}, \mathrm{H})=8 \mathrm{~Hz}, 2 \mathrm{H}, \mathrm{C}_{6} \mathrm{H}_{4}\right), 7.71\left(\mathrm{~d},{ }^{3} \mathrm{~J}(\mathrm{H}, \mathrm{H})=8 \mathrm{~Hz}, 2 \mathrm{H}\right.$, $\left.\mathrm{C}_{6} \mathrm{H}_{5}\right), 7.54-7.44\left(\mathrm{~m}, 3 \mathrm{H}, \mathrm{C}_{6} \mathrm{H}_{5}\right), 7.20\left(\mathrm{~d},{ }^{3} \mathrm{~J}(\mathrm{H}, \mathrm{H})=8 \mathrm{~Hz}, 2 \mathrm{H}, \mathrm{C}_{6} \mathrm{H}_{4}\right), 7.10\left(\mathrm{~d},{ }^{3} \mathrm{~J}(\mathrm{H}, \mathrm{H})=\right.$ $\left.8 \mathrm{~Hz}, 2 \mathrm{H}, \mathrm{C}_{6} \mathrm{H}_{4}\right), 6.90\left(\mathrm{~d},{ }^{3} \mathrm{~J}(\mathrm{H}, \mathrm{H})=8 \mathrm{~Hz}, 2 \mathrm{H}, \mathrm{C}_{6} \mathrm{H}_{4}\right), 6.75\left(\mathrm{~d},{ }^{3} \mathrm{~J}(\mathrm{H}, \mathrm{H})=8 \mathrm{~Hz}, 2 \mathrm{H}, \mathrm{C}_{6} \mathrm{H}_{4}\right)$, $6.38\left(\mathrm{~d},{ }^{3} \mathrm{~J}(\mathrm{H}, \mathrm{H})=16 \mathrm{~Hz}, 1 \mathrm{H}, \mathrm{C}_{6} \mathrm{H}_{4} \mathrm{CH}=\mathrm{CH}\right), 6.23\left(\mathrm{dt},{ }^{3} \mathrm{~J}(\mathrm{H}, \mathrm{H})=16 \mathrm{~Hz},{ }^{3} \mathrm{~J}(\mathrm{H}, \mathrm{H})=6 \mathrm{~Hz}\right.$, $\left.1 \mathrm{H}, \mathrm{C}_{6} \mathrm{H}_{4} \mathrm{CH}=\mathrm{CH}\right), 5.41\left(\mathrm{~d},{ }^{3} \mathrm{~J}(\mathrm{H}, \mathrm{H})=6 \mathrm{~Hz}, 1 \mathrm{H},\left(\mathrm{C}_{\mathrm{h}}\right) \mathrm{CH}=\mathrm{CH}\right), 4.83\left(\mathrm{~m}, 1 \mathrm{H}, \mathrm{OCH}\left(\mathrm{C}_{\mathrm{h}}\right)\right)$, $4.05\left(\mathrm{t}, 2 \mathrm{H},{ }^{3} \mathrm{~J}(\mathrm{H}, \mathrm{H})=6 \mathrm{~Hz}, \mathrm{CH}_{2} \mathrm{O}\right), 3.04\left(\mathrm{~s}, 2 \mathrm{H}, \mathrm{C}_{\mathrm{c}}-\mathrm{CH}_{2}\right), 2.42\left(\mathrm{~m}, 4 \mathrm{H}, \mathrm{OCHCH}_{2}\left(\mathrm{C}_{\mathrm{h}}\right)+\right.$ $\left.\mathrm{C}_{6} \mathrm{H}_{4} \mathrm{CH}=\mathrm{CHCH}_{2}\right), 0.91\left(\mathrm{~d},{ }^{3} \mathrm{~J}(\mathrm{H}, \mathrm{H})=6 \mathrm{~Hz}, 3 \mathrm{H}, \mathrm{CHCH}_{3}\right), 0.86\left(\mathrm{dd},{ }^{3} \mathrm{~J}(\mathrm{H}, \mathrm{H})=6 \mathrm{~Hz},{ }^{3} \mathrm{~J}(\mathrm{H}, \mathrm{H})\right.$ $\left.=3 \mathrm{~Hz}, 6 \mathrm{H}, \mathrm{CH}\left(\mathrm{CH}_{3}\right)_{2}\right), 0.68\left(\mathrm{~s}, 3 \mathrm{H}, \mathrm{C}-\mathrm{CH}_{3}\right) .{ }^{11} \mathrm{~B}\left\{{ }^{1} \mathrm{H}\right\} \mathrm{NMR}\left(\mathrm{CDCl}_{3}, \mathrm{BF}_{3} \cdot \mathrm{Et}_{2} \mathrm{O}\right), \delta(\mathrm{ppm})$ : -4.39 (2B), -10.92 (8B); ${ }^{13} \mathrm{C}\left\{{ }^{1} \mathrm{H}\right\}$ NMR ( $\left.\mathrm{CDCl}_{3}, \mathrm{TMS}\right), \delta(\mathrm{ppm}): 165.87$ (s, $\left.\mathrm{C}=\mathrm{O}\right), 162.74$ (s, $\left.\mathrm{C}_{a r} \mathrm{O}\right), 139.86\left(\mathrm{~s}, \mathrm{C}=\mathrm{CH}\left(\mathrm{C}_{\mathrm{h}}\right)\right), 137.15\left(\mathrm{~s}, \mathrm{C}_{6} \mathrm{H}_{4}\right), 133.99\left(\mathrm{~s}, \mathrm{C}_{6} \mathrm{H}_{4}\right), 131.62\left(\mathrm{~s}, \mathrm{C}_{6} \mathrm{H}_{4}\right), 131.59(\mathrm{~s}$, $\left.\mathrm{C}_{6} \mathrm{H}_{5}\right), 130.93\left(\mathrm{~s}, \mathrm{C}_{6} \mathrm{H}_{5}\right), 130.91\left(\mathrm{~s}, \mathrm{C}_{6} \mathrm{H}_{5}\right), 130.56\left(\mathrm{~s}, \mathrm{C}_{6} \mathrm{H}_{4}\right), 130.31\left(\mathrm{~s}, \mathrm{C}_{6} \mathrm{H}_{4} \mathrm{CH}=\mathrm{CH}\right), 130.21$ (s, $\left.\mathrm{C}_{6} \mathrm{H}_{4}\right), 130.10\left(\mathrm{~s}, \mathrm{C}_{6} \mathrm{H}_{4} \mathrm{CH}=\mathrm{CH}\right), 129.13\left(\mathrm{~s}, \mathrm{C}_{6} \mathrm{H}_{5}\right), 125.96\left(\mathrm{~s}, \mathrm{C}_{6} \mathrm{H}_{4}\right), 123.26\left(\mathrm{~s}, \mathrm{C}_{6} \mathrm{H}_{4}\right), 122.77$ (s, $\left.\mathrm{C}_{6} \mathrm{H}_{4}\right), 114.07\left(\mathrm{~s}, \mathrm{C}=\mathrm{CH}\left(\mathrm{C}_{\mathrm{h}}\right)\right), 83.76\left(\mathrm{~s}, \mathrm{C}_{c}-\mathrm{C}_{6} \mathrm{H}_{5}\right), 82.19\left(\mathrm{~s}, \mathrm{Cc}_{-}-\mathrm{CH}_{2}\right), 74.30(\mathrm{~s}, \mathrm{CH}-\mathrm{O}), 67.34(\mathrm{~s}$, $\left.\mathrm{CH}_{2}-\mathrm{O}\right), 56.79\left(\mathrm{~s}, \mathrm{CH}\left(\mathrm{C}_{\mathrm{p}}\right)\right), 56.22\left(\mathrm{~s}, \mathrm{CH}\left(\mathrm{C}_{\mathrm{p}}\right)\right), 50.13\left(\mathrm{~s}, \mathrm{CH}\left(\mathrm{C}_{\mathrm{h}}\right)\right), 42.41\left(\mathrm{~s}, \mathrm{CH}\left(\mathrm{C}_{\mathrm{p}}-\mathrm{C}_{\mathrm{h}}\right)\right)$, 40.72 (s, $\left.\mathrm{Cc}-\mathrm{CH}_{2}\right), 39.83$ (s, $\left.\mathrm{CH}_{2} \mathrm{CH}\left(\mathrm{CH}_{3}\right)_{2}\right), 39.61$ (s, $\left.\mathrm{CH}\left(\mathrm{C}_{\mathrm{h}}\right)\right), 38.39$ (s, $\left.\mathrm{CH}_{2} \mathrm{C}-\mathrm{O}\right), 37.15$ (s, $\left.\mathrm{CH}\left(\mathrm{C}_{\mathrm{h}}\right)\right), 36.75\left(\mathrm{~s}, \mathrm{CH}\left(\mathrm{C}_{\mathrm{h}}\right)\right), 36.28\left(\mathrm{~s}, \mathrm{CH}_{3} \mathrm{CHCH}_{2}\right), 35.90\left(\mathrm{~s}, \mathrm{CH}_{3} \mathrm{CHCH}_{2}\right), 32.03\left(\mathrm{~s}, \mathrm{CH}\left(\mathrm{C}_{\mathrm{h}}\right)\right)$, $31.97\left(\mathrm{~s}, \mathrm{CH}\left(\mathrm{C}_{\mathrm{h}}\right)\right), 29.46\left(\mathrm{~s}, \mathrm{CH}=\mathrm{CHCH}_{2} \mathrm{CH}_{2}\right), 28.82\left(\mathrm{~s}, \mathrm{CH}=\mathrm{CHCH}_{2} \mathrm{CH}_{2}\right), 28.34\left(\mathrm{~s}, \mathrm{CH}\left(\mathrm{C}_{\mathrm{h}}\right)\right)$, 28.11 (s, $\left.\mathrm{CH}\left(\mathrm{C}_{\mathrm{p}}\right)\right), 28.04$ (s, $\left.\mathrm{CH}-\left(\mathrm{CH}_{3}\right)_{2}\right), 24.39\left(\mathrm{~s}, \mathrm{CH}_{2}\left(\mathrm{C}_{\mathrm{p}}\right)\right), 23.93\left(\mathrm{~s}, \mathrm{CH}_{2} \mathrm{CH}_{2} \mathrm{CH}-\left(\mathrm{CH}_{3}\right)_{2}\right)$, $22.93\left(\mathrm{~s}, \mathrm{CH}-\left(\mathrm{CH}_{3}\right)_{2}\right), 22.67\left(\mathrm{~s}, \mathrm{CH}-\left(\mathrm{CH}_{3}\right)_{2}\right), 21.15\left(\mathrm{~s}, \mathrm{CH}\left(\mathrm{C}_{\mathrm{h}}\right)\right), 19.49\left(\mathrm{~s}, \mathrm{CH}-\mathrm{CH}_{3}\right), 18.82(\mathrm{~s}$, 
$\left.\mathrm{CH}-\mathrm{CH}_{3}\right), 11.96$ (s, CH-CH$)_{3}$. ATR ( $\mathrm{cm}^{-1}$ ): 2939 (br s, C-H st), 2584 (br s, B-H st), 1705 (s, $\mathrm{C}=\mathrm{O}$ st), 1604 (m, C=C st). MALDI-TOF-MS $\left(\mathrm{m} / \mathrm{z}\right.$ ): Calcd: 882.64 . Found: $921.57\left[\mathrm{M}+\mathrm{K}^{+}\right]$. Anal. Calcd. for $\mathrm{C}_{54} \mathrm{H}_{78} \mathrm{~B}_{10} \mathrm{O}_{3}: \mathrm{C}, 73.43 ; \mathrm{H}, 8.90$. Found: $\mathrm{C}, 72.89 ; \mathrm{H}, 8.92$.

\subsubsection{Synthesis of M5}

Compound M5 was synthesized using the same procedure as for M2, but using styrene $(0.5 \mathrm{~mL} 5.3 \mathrm{mmol}), \mathbf{M 1}(100 \mathrm{mg}, 0.17 \mathrm{mmol})$ and first-generation Grubbs catalyst $(20 \mathrm{mg}, 0.024 \mathrm{mmol})$ were dissolved in $\mathrm{CH}_{2} \mathrm{Cl}_{2}(5 \mathrm{~mL})$. After work-up, M5 was obtained as a pure white solid. Yield: $93 \mathrm{mg}, 82 \%$. A toluene solution of M5 gave crystals suitable for X-ray analysis. ${ }^{1} \mathrm{H} \mathrm{NMR}\left(\mathrm{CDCl}_{3}, \mathrm{TMS}\right), \delta(\mathrm{ppm}): 7.97\left(\mathrm{~d},{ }^{3} \mathrm{~J}(\mathrm{H}, \mathrm{H})=8 \mathrm{~Hz}, 2 \mathrm{H}, \mathrm{C}_{6} \mathrm{H}_{4}\right)$, 7.35-7.15 (m, 5H, $\left.\mathrm{C}_{6} H_{5}\right), 6.90\left(\mathrm{~d},{ }^{3} \mathrm{~J}(\mathrm{H}, \mathrm{H})=8 \mathrm{~Hz}, 2 \mathrm{H}, \mathrm{C}_{6} \mathrm{H}_{4}\right), 6.43\left(\mathrm{~d},{ }^{3} \mathrm{~J}(\mathrm{H}, \mathrm{H})=12 \mathrm{~Hz}, 1 \mathrm{H}\right.$, $\left.\mathrm{C}_{6} \mathrm{H}_{4} \mathrm{CH}=\mathrm{CH}\right), 6.23\left(\mathrm{dt},{ }^{3} \mathrm{~J}(\mathrm{H}, \mathrm{H})=12 \mathrm{~Hz},{ }^{3} \mathrm{~J}(\mathrm{H}, \mathrm{H})=4.5 \mathrm{~Hz}, 1 \mathrm{H}, \mathrm{C}_{6} \mathrm{H}_{4} \mathrm{CH}=\mathrm{CH}\right), 5.40(\mathrm{~d}$, $\left.{ }^{3} \mathrm{~J}(\mathrm{H}, \mathrm{H})=6 \mathrm{~Hz}, 1 \mathrm{H},\left(\mathrm{C}_{\mathrm{h}}\right) \mathrm{CH}=\mathrm{CH}\right), 4.81\left(\mathrm{~m}, 1 \mathrm{H}, \mathrm{OCH}\left(\mathrm{C}_{\mathrm{h}}\right)\right), 4.05\left(\mathrm{t}, 2 \mathrm{H},{ }^{3} \mathrm{~J}(\mathrm{H}, \mathrm{H})=6 \mathrm{~Hz}\right.$, $\left.\mathrm{CH}_{2} \mathrm{O}\right), 2.42\left(\mathrm{~m}, 2 \mathrm{H}, \mathrm{OCHCH}_{2}\left(\mathrm{C}_{\mathrm{h}}\right)\right), 1.06\left(\mathrm{~s}, 3 \mathrm{H}, \mathrm{C}-\mathrm{CH}_{3}\right), 0.91\left(\mathrm{~d},{ }^{3} \mathrm{~J}(\mathrm{H}, \mathrm{H})=6 \mathrm{~Hz}, 3 \mathrm{H}\right.$, $\left.\mathrm{CHCH}_{3}\right), 0.85\left(\mathrm{dd},{ }^{3} \mathrm{~J}(\mathrm{H}, \mathrm{H})=6 \mathrm{~Hz},{ }^{3} \mathrm{~J}(\mathrm{H}, \mathrm{H})=3 \mathrm{~Hz}, 6 \mathrm{H}, \mathrm{CH}\left(\mathrm{CH}_{3}\right)_{2}\right), 0.67\left(\mathrm{~s}, 3 \mathrm{H}, \mathrm{C}-\mathrm{CH}_{3}\right)$. ${ }^{13} \mathrm{C}\left\{{ }^{1} \mathrm{H}\right\}$ NMR (CDCl $\left.{ }_{3}, \mathrm{TMS}\right), \delta(\mathrm{ppm}): 165.89(\mathrm{~s}, \mathrm{C}=\mathrm{O}), 162.77\left(\mathrm{~s}, \mathrm{C}_{a r}-\mathrm{O}\right), 139.86$ (s, $\mathrm{C}=\mathrm{CH}$ $\left.\left(\mathrm{C}_{\mathrm{h}}\right)\right), 137.60\left(\mathrm{~s}, \mathrm{C}_{6} \mathrm{H}_{5}\right), 131.60\left(\mathrm{~s}, \mathrm{C}_{6} \mathrm{H}_{4}\right), 130.89\left(\mathrm{~s}, \mathrm{C}_{6} \mathrm{H}_{5}\right), 129.48\left(\mathrm{~s}, \mathrm{C}_{6} \mathrm{H}_{5}\right), 128.60\left(\mathrm{~s}, \mathrm{C}_{6} \mathrm{H}_{5}\right)$, $127.14\left(\mathrm{~s}, \mathrm{C}_{6} \mathrm{H}_{5}\right), 126.20\left(\mathrm{~s}, \mathrm{C}_{6} \mathrm{H}_{5}\right), 123.22\left(\mathrm{~s}, \mathrm{C}_{6} \mathrm{H}_{4}\right), 122.71\left(\mathrm{~s}, \mathrm{C}_{6} \mathrm{H}_{4}\right), 114.01(\mathrm{~s}, \mathrm{C}=\mathrm{CH}$ $\left.\left(\mathrm{C}_{\mathrm{h}}\right)\right), 74.27(\mathrm{~s}, \mathrm{CH}-\mathrm{O}), 67.36\left(\mathrm{~s}, \mathrm{CH}_{2}-\mathrm{O}\right), 56.78\left(\mathrm{~s}, \mathrm{CH}\left(\mathrm{C}_{\mathrm{p}}\right)\right), 56.21\left(\mathrm{~s}, \mathrm{CH}\left(\mathrm{C}_{\mathrm{p}}\right)\right), 50.12(\mathrm{~s}, \mathrm{CH}$ $\left.\left(\mathrm{C}_{\mathrm{h}}\right)\right), 42.40$ (s, $\left.\mathrm{CH}\left(\mathrm{C}_{\mathrm{p}}-\mathrm{C}_{\mathrm{h}}\right)\right), 39.82\left(\mathrm{~s}, \mathrm{CH}_{2} \mathrm{CH}\left(\mathrm{CH}_{3}\right)_{2}\right), 39.60$ (s, $\left.\mathrm{CH}\left(\mathrm{C}_{\mathrm{h}}\right)\right), 38.38$ (s, $\left.\mathrm{CH}_{2} \mathrm{C}-\mathrm{O}\right)$, $37.14\left(\mathrm{~s}, \mathrm{CH}\left(\mathrm{C}_{\mathrm{h}}\right)\right), 36.74\left(\mathrm{~s}, \mathrm{CH}\left(\mathrm{C}_{\mathrm{h}}\right)\right), 36.27\left(\mathrm{~s}, \mathrm{CH}_{3} \mathrm{CHCH}_{2}\right), 35.89\left(\mathrm{~s}, \mathrm{CH}_{3} \mathrm{CHCH}_{2}\right), 32.02$ (s, $\left.\mathrm{CH}\left(\mathrm{C}_{\mathrm{h}}\right)\right), 31.97\left(\mathrm{~s}, \mathrm{CH}\left(\mathrm{C}_{\mathrm{h}}\right)\right), 29.47\left(\mathrm{~s}, \mathrm{CH}=\mathrm{CHCH}_{2} \mathrm{CH}_{2}\right), 28.82\left(\mathrm{~s}, \mathrm{CH}=\mathrm{CHCH}_{2} \mathrm{CH}_{2}\right)$, $28.33\left(\mathrm{~s}, \mathrm{CH}\left(\mathrm{C}_{\mathrm{h}}\right)\right), 28.11\left(\mathrm{~s}, \mathrm{CH}\left(\mathrm{C}_{\mathrm{p}}\right)\right), 28.03\left(\mathrm{~s}, \mathrm{CH}-\left(\mathrm{CH}_{3}\right)_{2}\right), 24.38\left(\mathrm{~s}, \mathrm{CH}_{2}\left(\mathrm{C}_{\mathrm{p}}\right)\right), 23.91$ (s, $\left.\mathrm{CH}_{2} \mathrm{CH}_{2} \mathrm{CH}-\left(\mathrm{CH}_{3}\right)_{2}\right), 22.92\left(\mathrm{~s}, \mathrm{CH}-\left(\mathrm{CH}_{3}\right)_{2}\right), 22.66\left(\mathrm{~s}, \mathrm{CH}-\left(\mathrm{CH}_{3}\right)_{2}\right), 21.13\left(\mathrm{~s}, \mathrm{CH}\left(\mathrm{C}_{\mathrm{h}}\right)\right), 19.48$ (s, $\left.\mathrm{CH}-\mathrm{CH}_{3}\right), 18.81\left(\mathrm{~s}, \mathrm{CH}-\mathrm{CH}_{3}\right), 11.95$ ppm (s, CH-CH $\mathrm{CH}_{3}$. ATR $\left(\mathrm{cm}^{-1}\right)$ : 2931 (br s, C-H st), 1697 (s, C=O st), 1604 (m, C=C st). MALDI-TOF-MS ( $\mathrm{m} / \mathrm{z}$ ): Calcd: 650.47. Found: 673.46 $\left[\mathrm{M}+\mathrm{Na}^{+}\right]$. Anal. Calcd. for $\mathrm{C}_{45} \mathrm{H}_{62} \mathrm{O}_{3}: \mathrm{C}, 83.03 ; \mathrm{H}, 9.60$. Found: $\mathrm{C}, 81.92 ; \mathrm{H}, 9.55 .(+1 / 2$ $\mathrm{MeOH} \mathrm{C}_{45.5} \mathrm{H}_{64} \mathrm{O}_{3.5}$ : $\left.\mathrm{C}, 81.99 ; \mathrm{H}, 9.60\right)$.

\section{Conclusions}

In conclusion, the olefin cross-metathesis between suitably substituted $o$-carborane derivatives and a mesogenic precursor as the modified cholesterol offers a strategy to obtain liquid crystalline materials. The reaction of styrenyl-o-carborane derivatives with a terminal alkenyl cholesteryl benzoate yields only the desired trans-regioisomer, which is the best-suited configuration to attain mesogenic behavior. The substituent linked to the $\mathrm{C}_{\mathrm{C}}$ atom of the o-carborane plays an important role in tuning the liquid crystal behavior; for non-substituted $o$-carborane $(\mathbf{M} 2, \mathrm{R}=\mathrm{H})$ and methyl-substituted $o$-carborane (M3, $\mathrm{R}=\mathrm{Me})$, the $\mathrm{N}^{*}$ phase was obtained, whereas $\mathrm{M} 4(\mathrm{R}=\mathrm{Ph})$ was not mesogenic. In addition, M3 exhibited blue phase, which was observed neither in the chiral nematic precursor M1 nor in the model compound M5, which suggested that the presence of the $o$-carborane cluster leads to stabilizing this highly twisted chiral phase in this set of compounds. In these cases, although the thermal stability and the range of the $\mathrm{N}^{*}$ phase is substantially decreased in comparison with the precursors, the $o$-carborane cluster can be incorporated without destroying the helical organization of the mesophase.

Supplementary Materials: The following are available online at https:/ / www.mdpi.com/2073-435 2/11/2/133/s1. Scheme S1. Synthesis of the mesogen M1, Figure S1. ${ }^{1} \mathrm{H}-\mathrm{NMR}$ of compound M2, Figure S2. ${ }^{11} \mathrm{~B}\left\{{ }^{1} \mathrm{H}\right\}$-NMR of compound M2, Figure S3. ${ }^{13} \mathrm{C}\left\{{ }^{1} \mathrm{H}\right\}$-NMR of compound M2, Figure S4. ${ }^{1} \mathrm{H}-\mathrm{NMR}$ of compound M3, Figure S5. ${ }^{11} \mathrm{~B}\left\{{ }^{1} \mathrm{H}\right\}-\mathrm{NMR}$ of compound M3, Figure S6. ${ }^{13} \mathrm{C}\left\{{ }^{1} \mathrm{H}\right\}-\mathrm{NMR}$ of compound M3, Figure S7. ${ }^{1} \mathrm{H}-\mathrm{NMR}$ of compound M4, Figure S8. ${ }^{11} \mathrm{~B}\left\{{ }^{1} \mathrm{H}\right\}-\mathrm{NMR}$ of compound M4, Figure S9. ${ }^{13} \mathrm{C}\left\{{ }^{1} \mathrm{H}\right\}-\mathrm{NMR}$ of compound M4, Figure S10. ${ }^{1} \mathrm{H}-\mathrm{NMR}$ of compound M5, Figure S11. ${ }^{13} \mathrm{C}\left\{{ }^{1} \mathrm{H}\right\}-\mathrm{NMR}$ of compound M5, Figure S12. FT-IR of compound M2, Figure S13. FT-IR of compound M3, Figure S14. FT-IR of compound M4, Figure S15. FT-IR of compound M5, Figure S16. View of independent molecules in the unit cell of M2 (A) and M3 (B) with numbering, Figure S17. View of independent molecules in the unit cell of M5 with numbering, Figure S18. Views of crystal packings 
of M2 (A), M3 (B) and M5 (C) are shown in the left. Detail view of molecular self-assembly is shown in the right. Independent molecules in the unit cells are colored. $\mathrm{H}$ atoms are omitted for clarity, Figure S19. Comparison between 2D fingerprint plots for M2 (A), M3 (B) and M5 (C), Figure S20. Normalized UV-Visible and fluorescence spectra of M2-M3 and M5, Figure S21. DSC of compound $\mathbf{M} 2\left(3\right.$ cycles at $\left.10{ }^{\circ} \mathrm{C} / \mathrm{min}\right)$, Figure S22. DSC of compound $\mathbf{M} 3\left(3\right.$ cycles at $\left.10^{\circ} \mathrm{C} / \mathrm{min}\right)$, Figure S23. DSC of compound M4 (3 cycles at $\left.10{ }^{\circ} \mathrm{C} / \mathrm{min}\right)$, Figure S24. DSC of compound M5 (3 cycles at $10{ }^{\circ} \mathrm{C} / \mathrm{min}$ ), Figure S25. Selected POM images of compound M2. Left side: Registered at $132{ }^{\circ} \mathrm{C}$ during the cooling cycle (rate $1{ }^{\circ} \mathrm{C} / \mathrm{min}$ ), showing $\mathrm{N}^{*}$ phase. Right side: Registered at $119^{\circ} \mathrm{C}$ during the cooling cycle (rate $1^{\circ} \mathrm{C} / \mathrm{min}$ ), showing the transition from $\mathrm{N}^{*}$ to crystalline phase, Figure S26. Selected POM images of compound M5, registered at $204.3^{\circ} \mathrm{C}$ during the cooling cycle (rate $0.5^{\circ} \mathrm{C} / \mathrm{min}$ ), showing $\mathrm{N}^{*}$ phase from Isotropic, Table S1. Crystal and Structure Refinement data for M2, M3 and M5, Table S2. Selected bond lengths for M2, M3 and M5, Table S3. Bond lengths for M2, M3 and M5, Table S4. Bond angles for M2, M3 and M5.

Author Contributions: Manuscript conception, R.N. and I.M.S.; writing and original draft preparation, R.N. and I.M.S.; synthesis and characterization of derivatives M2-M5, A.F.-U. and A.G.-C.; photophysical and liquid crystal, A.F.-U. and A.G.-C.; X-ray analysis, J.G.P.; editing, data analysis and interpretation, A.F.-U., A.G.-C., F.T., C.V., R.N. and I.M.S. All authors have read and agreed to the published version of the manuscript.

Funding: This research was funded by MICINN grants (PID2019-106832RB-100 and CEX2019-000917S) and Generalitat de Catalunya (2017/SGR/1720).

Acknowledgments: This work was supported by Agencia Estatal de Investigación AEI from MICINN (CTQ2016-75150-R and PID2019-106832RB-100/AEI/10.13039/501100011033 project) and Generalitat de Catalunya (2017 SGR1720 projects). The work was also supported by the MICINN through the Severo Ochoa Program for Centers of Excellence FUNFUTURE (CEX2019-000917-S). We gratefully acknowledge A. Whitwood for collecting the X-ray single crystals diffraction pattern.

Conflicts of Interest: The authors declare no conflict of interest. The funders had no role in the design of the study; in the collection, analyses, or interpretation of data; in the writing of the manuscript, or in the decision to publish the results.

\section{References}

1. Saez, I.M. Supermolecular Liquid Crystals. In Handbook of Liquid Crystals, 2nd ed.; Goodby, J.W., Collings, P.J., Kato, T., Tschierske, C., Gleeson, H., Raynes, P., Vill, V., Eds.; Wiley-VCH: Weinheim, Germany, 2014; Volume 7, pp. $211-258$.

2. Saez, I.M. Supermolecular Liquid Crystals. In Supramolecular Soft Matter; Nakanishi, T., Ed.; Wiley: Hoboken, NJ, USA, 2011; pp. 301-321.

3. Saez, I.M.; Goodby, J.W. Supermolecular Liquid Crystals. In Liquid Crystalline Functional Assemblies and Their Supramolecular Structures, Structure and Bonding; Kato, T., Ed.; Springer: Berlin/Heidelberg, Germany, 2008; Volume 128, pp. 1-62.

4. Wang, Y.; Li, Q. Light-Driven Chiral Molecular Switches or Motors in Liquid Crystals. Adv. Mater. 2012, 24, 1926. [CrossRef]

5. Mulder, D.J.; Schenning, A.; Bastiaansen, C.W.M. Chiral-nematic liquid crystals as one-dimensional photonic materials in optical sensors. J. Mater. Chem. C 2014, 2, 6695-6705. [CrossRef]

6. Moirangthem, M.; Arts, R.; Merkx, M.; Schenning, A.P. An optical sensor based on a photonic polymer film to detect calcium in serum. Adv. Funct. Mater. 2016, 26, 1154-1160. [CrossRef]

7. Ryabchun, A.; Lancia, F.; Chen, J.; Morozov, D.; Feringa, B.L.; Katsonis, N. Helix Inversion Controlled by Molecular Motors in Multistate Liquid Crystals. Adv. Mater. 2020, 32, 2004420. [CrossRef]

8. Grimes, R.N. Carboranes, 3rd ed.; Academic Press: Cambridge, MA, USA, 2016.

9. Issa, F.; Kassiou, M.; Rendina, L.M. Boron in drug discovery: Carboranes as unique pharmacophores in biologically active compounds. Chem. Rev. 2011, 111, 5701-5722. [CrossRef] [PubMed]

10. Scholz, M.; Hey-Hawkins, E. Carbaboranes as Pharmacophores: Properties, Synthesis, and Application Strategies. Chem. Rev. 2011, 111, 7035-7062. [CrossRef] [PubMed]

11. Stockmann, P.; Gozzi, M.; Kuhnert, R.; Sárosi, M.B.; Hey-Hawkins, E. New keys for old locks: Carborane-containing drugs as platforms for mechanism-based therapies. Chem. Soc. Rev. 2019, 48, 3497-3512. [CrossRef] [PubMed]

12. Chen, Z.; King, R.B. Spherical Aromaticity: Recent Work on Fullerenes, Polyhedral Boranes, and Related Structures. Chem. Rev. 2005, 105, 3613-3642. [CrossRef]

13. Poater, J.; Solà, M.; Viñas, C.; Teixidor, F. A Simple Link between Hydrocarbon and Borohydride Chemistries. Chem. Eur. J. 2013, 19, 4169-4175. [CrossRef]

14. Poater, J.; Solà, M.; Viñas, C.; Teixidor, F. $\pi$-Aromaticity and three-dimensional aromaticity: Two sides of the same coin? Angew. Chem. Int. Ed. 2014, 53, 12191-12195. [CrossRef] 
15. Poater, J.; Sola, M.; Viñas, C.; Teixidor, F. Huckel's Rule of Aromaticity Categorizes Aromatic closo Boron Hydride Clusters. Chem. Eur. J. 2016, 22, 7437-7443. [CrossRef] [PubMed]

16. Poater, J.; Viñas, C.; Bennour, I.; Escayola, S.; Sola, M.; Teixidor, F. Too Persistent to Give Up: Aromaticity in Boron Clusters Survives Radical Structural Changes. J. Am. Chem. Soc. 2020, 142, 9396-9407. [CrossRef] [PubMed]

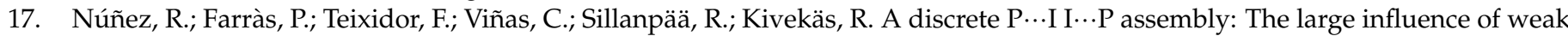
interactions on the ${ }^{31}$ P NMR Spectra of Phosphane-Diiodine Complexes. Angew. Chem. Int. Ed. 2006, 45, 1270-1272. [CrossRef] [PubMed]

18. Núñez, R.; Teixidor, F.; Kivekäs, R.; Sillanpää, R.; Viñas, C. Influence of the solvent and R groups on the structure of (carboranyl) $\mathrm{R}_{2} \mathrm{PI}_{2}$ compounds in solution. Crystal structure of the first iodophosphonium salt incorporating the anion [7,8-nidoC2B9H10]-. Dalton Trans. 2008, 1471-1480.

19. Kolel-Veetil, M.K.; Keller, T.M. Formation of elastomeric network polymers from ambient heterogeneous hydrosilations of carboranylenesiloxane and branched siloxane monomers. Polym. Sci. Part A 2006, 44, 147-155. [CrossRef]

20. Ferrer-Ugalde, A.; Juárez-Pérez, E.J.; Teixidor, F.; Viñas, C.; Núñez, R. Synthesis, Characterization, and Thermal Behavior of Carboranyl-Styrene Decorated Octasilsesquioxanes: Influence of the Carborane Clusters on Photoluminescence. Chem. Eur. J. 2013, 19, 17021-17030. [CrossRef]

21. Núñez, R.; Romero, I.; Teixidor, F.; Viñas, C. Icosahedral boron clusters: A perfect tool for the enhancement of polymer features. Chem. Soc. Rev. 2016, 45, 5147-5173. [CrossRef]

22. Hosmane, N.S. Boron Science: New Technologies and Applications; Taylor \& Francis: Bosa Roca, USA, 2012.

23. González-Campo, A.; Ferrer-Ugalde, A.; Viñas, C.; Teixidor, F.; Sillanpää, R.; Rodríguez-Romero, J.; Santillan, R.; Farfán, N.; Núñez, R. A Versatile Methodology for the Controlled Synthesis of Photoluminescent High-Boron-Content Dendrimers. Chem. Eur. J. 2013, 19, 6299-6312. [CrossRef]

24. Hosmane, N.S.; Eagling, R. Handbook of Boron Chemistry in Organometallics Catalysis, Materials and Medicine; World Science Publishers: Hackensack, NJ, USA, 2018.

25. Teixidor, F.; Viñas, C.; Demonceau, A.; Nuñez, R. Boron clusters: Do they receive the deserved interest? Pure Appl. Chem. 2003, 75, 1305-1313. [CrossRef]

26. Lesnikowski, Z.J. Boron units as pharmacophores-New applications and opportunities of boron cluster chemistry. Collect. Czechoslov. Chem. Commun. 2007, 72, 1646-1658. [CrossRef]

27. Dash, B.P.; Satapathy, R.; Gaillard, E.R.; Norton, K.M.; Maguire, J.A.; Chug, N.; Hosmane, N.S. Enhanced $\pi$-conjugation and emission via icosahedral carboranes: Synthetic and spectroscopic investigation. Inorg. Chem. 2011, 50, 5485-5493. [CrossRef] [PubMed]

28. Weber, L.; Kahlert, J.; Brockhinke, R.; Bohling, L.; Brockhinke, A.; Stammler, H.-G.; Neumann, B.; Harder, R.A.; Fox, M.A. Luminescence properties of C-diazaborolyl-ortho-carboranes as donor-acceptor systems. Chem. Eur. J. 2012, 18, 8347-8357. [CrossRef] [PubMed]

29. Wee, K.-R.; Cho, Y.-J.; Song, J.K.; Kang, S.O. Multiple photoluminescence from 1,2-dinaphthyl-ortho-carborane. Angew. Chem. Int. Ed. 2013, 52, 9682-9685. [CrossRef] [PubMed]

30. Guo, J.; Liu, D.; Zhang, J.; Zhang, J.; Miao, Q.; Xie, Z. o-Carborane functionalized pentacenes: Synthesis, molecular packing and ambipolar organic thin-film transistors. Chem. Commun. 2015, 51, 12004-12007. [CrossRef]

31. Kim, S.-Y.; Lee, A.-R.; Jin, G.F.; Cho, Y.-J.; Son, H.-J.; Han, W.-S.; Kang, S.O. Lectronic Alteration on Oligothiophenes by oCarborane: Electron Acceptor Character of o-Carborane in Oligothiophene Frameworks with Dicyano-Vinyl End-On Group. J. Org. Chem. 2015, 80, 4573-4580. [CrossRef] [PubMed]

32. Park, J.; Lee, Y.H.; Ryu, J.Y.; Lee, J.; Lee, M.H. The substituent effect of 2-R-o-carborane on the photophysical properties of iridium(iii) cyclometalates. Dalton Trans. 2016, 45, 5667-5675. [CrossRef]

33. Tu, D.; Leong, P.; Li, Z.; Hu, R.; Shi, C.; Zhang, K.Y.; Yan, H.; Zhao, Q. A carborane-triggered metastable charge transfer state leading to spontaneous recovery of mechanochromic luminescence. Chem. Commun. 2016, 52, 12494-12497. [CrossRef]

34. Núñez, R.; Tarrès, M.; Ferrer-Ugalde, A.; de Biani, F.F.; Teixidor, F. Electrochemistry and Photoluminescence of Icosahedral Carboranes, Boranes, Metallacarboranes, and Their Derivatives. Chem. Rev. 2016, 116, 14307-14378. [CrossRef]

35. Mukherjee, S.; Thilagar, P. Boron clusters in luminescent materials. Chem. Commun. 2016, 52, 1070-1093. [CrossRef]

36. Naito, H.; Nishino, K.; Morisaki, Y.; Tanaka, K.; Chujo, Y. Solid-State Emission of the Anthracene-o-Carborane Dyad from the Twisted-Intramolecular Charge Transfer in the Crystalline State. Angew. Chem. Int. Ed. 2017, 56, 254-259. [CrossRef]

37. Wu, X.; Guo, J.; Quan, Y.; Jia, W.; Jia, D.; Chen, Y.; Xie, Z. Cage carbon-substitute does matter for aggregation-induced emission features of o-carborane-functionalized anthracene triads. J. Mater. Chem. C 2018, 6, 4140-4149. [CrossRef]

38. Nghia, N.V.; Jana, S.; Sujith, S.; Ryu, J.Y.; Lee, J.; Lee, S.U.; Lee, M.H. Nido-Carboranes: Donors for Thermally Activated Delayed Fluorescence. Angew. Chem. Int. Ed. 2018, 57, 12483-12488. [CrossRef] [PubMed]

39. Martin, K.L.; Smith, J.N.; Young, E.R.; Carter, K.R. Synthetic Emission Tuning of Carborane-Containing Poly(dihexylfluorene)s. Macromolecules 2019, 52, 7951-7960. [CrossRef]

40. Wei, X.; Zhu, M.-J.; Cheng, Z.; Lee, M.; Yan, H.; Lu, C.; Xu, J.J. Aggregation-Induced Electrochemiluminescence of Carboranyl Carbazoles in Aqueous Media. Angew. Chem. 2019, 131, 3194-3198. [CrossRef]

41. Ochi, J.; Tanaka, K.; Chujo, Y. Recent Progress in the Development of Solid-State Luminescent o-Carboranes with Stimuli Responsivity. Angew. Chem. Int. Ed. 2020, 59, 9841-9855. [CrossRef] 
42. Ferrer-Ugalde, A.; Juárez-Pérez, E.J.; Teixidor, F.; Viñas, C.; Sillanpää, R.; Pérez Inestrosa, E.; Núñez, R. Synthesis and Characterization of New Fluorescent Styrene Containing Carborane Derivatives. The singular quenching role of a Phenyl Substituent. Chem. Eur. J. 2012, 18, 544-553. [CrossRef]

43. Ferrer-Ugalde, A.; González-Campo, A.; Viñas, C.; Rodríguez-Romero, J.; Santillan, R.; Farfán, N.; Sillanpää, R.; Sousa-Pedrares, A.; Núñez, R.; Teixidor, F. Fluorescence of New o-Carborane Compounds with Different Fluorophores: Can It Be Tuned? Chem. Eur. J. 2014, 20, 9940-9951. [CrossRef]

44. Cabrera-González, J.; Viñas, C.; Haukka, M.; Bhattacharyya, S.; Gierschner, J.; Núñez, R. Photoluminescence in Carborane-Stilbene Triads: A Structural, Spectroscopic, and Computational Study. Chem. Eur. J. 2016, 22, 13588-13598. [CrossRef]

45. Cabrera-González, J.; Bhattacharyya, S.; Milián-Medina, B.; Teixidor, F.; Farfán, N.; Arcos-Ramos, R.; Vargas-Reyes, V.; Gierschner, J.; Núñez, R. Tetrakis\{[(p-dodecacarboranyl)methyl]stilbenyl\}ethylene: A Luminescent Tetraphenylethylene (TPE) Core System. Eur. J. Inorg. Chem. 2017, 4575-4580. [CrossRef]

46. Ferrer-Ugalde, A.; Cabrera-González, J.; Juárez-Pérez, E.J.; Teixidor, F.; Pérez-Inestrosa, E.; Montenegro, J.M.; Sillanpää, R.; Haukka, M.; Núñez, R. Carborane-stilbene dyads: The influence of substituents and cluster isomers on photoluminescence properties. Dalton Trans. 2017, 46, 2091-2104. [CrossRef] [PubMed]

47. Cabrera-González, J.; Ferrer-Ugalde, A.; Bhattacharyya, S.; Chaari, M.; Teixidor, F.; Gierschner, J.; Núñez, R. Fluorescent carboranevinylstilbene functionalised octasilsesquioxanes: Synthesis, structural, thermal and photophysical properties. J. Mater. Chem. C 2017, 5, 10211-10219. [CrossRef]

48. Bellomo, C.; Chaari, M.; Cabrera-González, J.; Blangetti, M.; Lombardi, C.; Deagostino, A.; Viñas, C.; Gaztelumendi, N.; Nogués, C.; Nuñez, R.; et al. Carborane-BODIPY Dyads: New Photoluminescent Materials through an Efficient Heck Coupling. Chem. Eur. J. 2018, 24, 15622-15630. [CrossRef] [PubMed]

49. Li, X.-Q.; Wang, C.-H.; Zhang, M.-Y.; Zou, H.-Y.; Ma, N.-N.; Qiu, Y.-Q. Tuning second-order nonlinear optical properties of the twodimensional benzene/carborane compounds with phenyl carbazoles: Substituent effect and redox switch. J. Organomet. Chem. 2014, 749, 327-334. [CrossRef]

50. Wang, J.; Wang, W.-Y.; Fang, X.-Y.; Qiu, Y.-Q. Carborane tuning on iridium complexes: Redox-switchable second-order NLO responses. J. Mol. Model. 2015, 21, 95. [CrossRef]

51. Kaszynski, P. Boron Science: New Technologies and Applications; Hosmane, N.S., Ed.; CRC Press \& Taylor and Frances Group: Boca Raton, FL, USA, 2012; p. 319.

52. Nagamine, T.; Januszko, A.; Ohta, K.; Kaszynski, P.; Endo, Y. The effect of the linking group on mesogenic properties of three-ring derivatives of p-carborane and biphenyl. Liq. Cryst. 2008, 35, 865-884. [CrossRef]

53. Piecek, W.; Glab, K.L.; Januszko, A.; Perkowski, P.; Kaszynski, P. Modification of electro-optical properties of an orthoconic chiral biphenyl smectogen with its isostructural carborane analogue. J. Mater. Chem. 2009, 19, 1173-1182. [CrossRef]

54. Ringstrand, B.; Jankowiak, A.; Johnson, L.E.; Kaszynski, P.; Pociechacand, D.; Górecka, E. Anion-driven mesogenicity: A comparative study of ionic liquid crystals basedon the [closo-1-CB9H10]- and [closo-1-CB11H12]- clusters. J. Mater. Chem. 2012, 22, 4874-4880. [CrossRef]

55. Pecyna, J.; Pociecha, D.; Kaszynski, P. Zwitterionic pyridinium derivatives of [closo-1-CB9H10]- and [closo-1-CB11H12]- clusters as as high De additives to a nematic host. J. Mater. Chem. C 2014, 2, 1585-1591. [CrossRef]

56. Fisher, S.P.; Tomich, A.W.; Lovera, S.O.; Kleinsasser, J.F.; Guo, J.; Asay, M.J.; Nelson, H.M.; Lavallo, V. Nonclassical Applications of closo-Carborane Anions: From Main Group Chemistry and Catalysis to Energy Storage. Chem. Rev. 2019, 119, 8262-8290. [CrossRef] [PubMed]

57. Ali, M.O.; Lasseter, J.C.; Żurawiński, R.; Pietrzak, A.; Pecyna, J.; Wojciechowski, J.; Friedli, A.C.; Pociecha, D.; Kaszyński, P. Thermal and Photophysical Properties of Highly Quadrupolar Liquid-Crystalline Derivatives of the [closo-B12H12](2-) Anion. Chem. Eur. J. 2019, 25, 2616-2630. [CrossRef]

58. Ringstrand, B.; Kaszynski, P. Investigation of high $\Delta \varepsilon$ derivatives of the [closo-1-CB9H10]- anion for liquid crystal display applications. J. Mat. Chem. 2011, 21, 90-95. [CrossRef]

59. Pecyna, J.; Denicola, R.P.; Gray, H.M.; Ringstrand, B.; Kaszynski, P. The effect of molecular polarity on nem/catic phase stability in 12-vertex carboranes. Liq. Cryst. 2014, 41, 1188-1198. [CrossRef]

60. Januszko, A.; Glab, K.L.; Kaszynski, P. Induction of smectic behaviour in a carborane-containing mesogen. Tail fluorination of a threering nematogen and its miscibility with benzene analogues. Liq. Cryst. 2008, 35, 549. [CrossRef]

61. Feakes, D.A.; Spinler, J.K.; Harris, F.R. Synthesis of boron-containing cholesterol derivatives for incorporation into unilamellar liposomes and evaluation as potential agents for BNCT. Tetrahedron 1999, 55, 11177-11186. [CrossRef]

62. Nakamura, H.; Miyajima, Y.; Takei, T.; Kasaoka, S.; Maruyama, K. Synthesis and vesicle formation of a nido-carborane cluster lipid for boron neutron capture therapy. Chem. Commun. 2004, 1910-1911. [CrossRef] [PubMed]

63. Feakes, D.A.; Shelly, K.; Hawthorne, M.F. Selective boron delivery to murine tumors by lipophilic species incorporated in the membranes of unilamellar liposomes. Proc. Natl. Acad. Sci. USA 1995, 92, 1367-1370. [CrossRef] [PubMed]

64. Bregadze, V.I.; Sivaev, I.B.; Dubey, R.D.; Semioshkin, A.; Shmal'ko, A.V.; Kosenko, I.D.; Lebedeva, K.V.; Mandal, S.; Sreejyothi, P.; Sarkar, A.; et al. Boron-Containing Lipids and Liposomes: New Conjugates of Cholesterol with Polyhedral Boron Hydrides. Chem. Eur. J. 2020, 20, 13832-13841. [CrossRef] [PubMed]

65. Jankowiak, A.; Kaszynski, P. Practical Synthesis of 1,12-Difunctionalized o-Carborane for the Investigation of Polar Liquid Crystals. Inorg. Chem. 2014, 53, 8762-8769. [CrossRef] [PubMed] 
66. Pecyna, J.; Jankowiak, A.; Pociecha, D.; Kaszyński, P. o-Carborane derivatives for probing molecular polarity effects on liquid crystal phase stability and dielectric behavior. J. Mater. Chem. C. 2015, 3, 11412-11422. [CrossRef]

67. Saez, I.M.; Goodby, J.W. Chiral nematic octasilsesquioxanes. J. Mater. Chem. 2001, 11, 2845-2855. [CrossRef]

68. Saez, I.M.; Goodby, J.W.; Richardson, R.M. A liquid-crystalline silsesquioxane dendrimer exhibiting chiral nematic and columnar mesophases. Chem. Eur. J. 2001, 2758-2764. [CrossRef]

69. Felder-Flesch, D.; Rupnicki, L.; Bourgogne, C.; Donnio, B.; Guillon, D. Liquid-crystalline cholesterol-based [60]fullerene hexaadducts. J. Mater. Chem. 2006, 16, 304-309. [CrossRef]

70. Campidelli, S.; Brandmüller, T.; Hirsch, A.; Saez, I.M.; Goodby, J.W.; Deschenaux, R. An Optically-active Liquid-crystalline Hexa-adduct of [60]Fullerene which Displays Supramolecular Helical Organization. Chem. Comm. 2006, 41, 4282-4284. [CrossRef] [PubMed]

71. Campidelli, S.; Bourgun, P.; Guintchin, B.; Furrer, J.; Stoeckli-Evans, H.; Saez, I.M.; Goodby, J.W.; Deschenaux, R. Diastereoisomerically Pure Fulleropyrrolidines as Chiral Platforms for the Design of Optically Active Liquid Crystals. J. Am. Chem. Soc. 2010, 132, 3574-3581. [CrossRef]

72. Gresham, K.D.; McHugh, C.M.; Bunning, T.J.; Crane, R.L.; Klei, H.E.; Samulski, E.T. Phase behavior of cyclic siloxane-based liquid crystalline compounds. J. Polym. Sci. Part A Polym. Chem. 1994, 32, 2039-2047. [CrossRef]

73. Trinh, T.M.N.; Nguyen, T.T.; Kopp, C.; Pieper, P.; Ruso, V.; Heinrich, B.; Donnio, B.; Nguyen, T.L.A.; Deschenaux, R. Olefin CrossMetathesis: A Versatile Synthetic Reaction for the Design of Janus Liquid Crystals. Eur. J. Org. Chem. 2015, 27, 6005-6010. [CrossRef]

74. Russo, V.; Pieper, P.; Heinrich, B.; Donnio, B.; Deschenaux, R. Design, Synthesis, and Self-Assembly Behavior of Liquid Crystalline Bis-[60]Fullerodendrimers. Chem. Eur. J. 2016, 22, 17366-17376. [CrossRef]

75. Zep, A.; Pruszkowska, K.; Dobrzycki, Ł.; Sektas, K.; Szałański, P.; Marek, P.H.; Cyrański, M.K.; Sicinski, R.R. Cholesterol-based photo-switchable mesogenic dimers. Strongly bent molecules versus an intercalated structure. CrystEngComm 2019, 21, 2779-2789. [CrossRef]

76. Fox, M.A.; Hughes, A.K. Cage C-H ‥X interactions in solid-state structures of icosahedral carboranes. Coord. Chem. Rev. 2004, 248, 457-476. [CrossRef]

77. Turn, M.J.; McKinnon, J.J.; Wolff, S.K.; Grimwood, D.J.; Spackman, P.R.; Jayatilaka, D.; Spackman, M.A. CrystalExplorer17. University of Western Australia, 2017. Available online: https:/ / crystalexplorer.scb.uwa.edu.au (accessed on 27 January 2021).

78. Di Salvo, F.; Camargo, B.; Garcia, Y.; Teixidor, F.; Viñas, C.; Giner Planas, J.; Light, M.E.; Hursthouse, M.B. Supramolecular architectures in o-carboranyl alcohols bearing N-aromatic rings: Syntheses, crystal structures and melting points correlation. CrystEngComm 2011, 13, 5788-5806. [CrossRef]

79. Dierking, I. Textures of Liquid Crystals; Wiley-VCH Verlag GmbH \& Co. KGaA: Weinheim, Germany, 2003.

80. Cowling, S.J.; Hall, A.W.; Goodby, J.W. Effect of terminal functional group size on ferroelectric and antiferroelectric properties of liquid crystals. Liq. Cryst. 2005, 32, 1483-1498. [CrossRef]

81. Oxford Diffraction Ltd. CrysAlisPro. Version 1.171.34.40 (Release 27-08-2010 CrysAlis171. NET) (Compiled 27 August 2010, 11:50:40) Empirical Absorption Correction using Spherical Harmonics, Implemented in SCALE3 ABSPACK Scaling Algorithm; Oxford Diffraction Ltd.: Abingdon, UK, 2010.

82. Sheldrick, G.M. A short history of SHELX. Acta Cryst. 2008, A64, 112-122. [CrossRef] [PubMed]

83. Palatinus, L.; Chapuis, G. SUPERFLIP-A computer program for the solution of crystal structures by charge flipping in arbitrary dimensions. J. Appl. Cryst. 2007, 40, 786-790. [CrossRef]

84. Dolomanov, O.V.; Bourhis, L.J.; Gildea, R.J.; Howard, J.A.; Puschmann, H. OLEX2: A complete structure solution, refinement and analysis program. J. Appl. Crystallogr. 2009, 42, 339-341. [CrossRef] 